\title{
REVEGETATION OF FLY ASH - A REVIEW WITH EMPHASIS ON GRASS-LEGUME PLANTATION AND BIOACCUMULATION OF METALS
}

\author{
MAITI, D. ${ }^{*}-$ PRASAD, B. ${ }^{1}$ \\ Academy of Scientific and Innovative Research (AcSIR), Environment Management Divison, \\ CSIR-Central Institute of Mining and Fuel Research, Dhanbad-826015, India \\ ${ }^{1}$ e-mail: drbablyprasad@yahoo.com \\ (phone: +91-326-2296027; 2296028; 2296029; ext-4392; +91-9431122060(m)) \\ *Corresponding author \\ e-mail:dmhellodeblina@gmail.com \\ (phone.: +91-8987414586, 7209751385) \\ (Received $11^{\text {th }}$ Aug 2015; accepted $16^{\text {th }}$ Feb 2016)
}

\begin{abstract}
Uninterrupted generation of fly ash by the coal based thermal power plants and its dumping has lead to steady encroachment of useful land in India. The deleterious effects of fly ash on the nearby environment are inevitable due to its fine texture and presence of toxic metals. Thus, proper revegetation programme of the sites are highly desirable due to their continuance in being the part of landscape. This paper conglomerates all the issues which should be taken into account to prevent groundwater contamination and increase phytostabilization of metals. An insight to the past and the prevailing restoration scenario will help in selecting of plant species for biomass production. Primarily, an integrated approach towards revegetation is necessary which comprises native and exotic grass-legume species, readily available composts, green manure, and mulches. The paucity of studies in relation to the long term changes in fly ash due to vegetation is to be permeated through regular analysis of substrate nutrient status, extent of nutrient loss, bioavailable toxic metals, in restoration sites. The range of methodologies and indexes discussed here will benefit the future management approaches of fly ash with emphasis on phytoremediation of trace metals, development of aesthetically pleasant landscape and productivity.

Keywords: bioaccumulation factor, translocation factor, maximum allowable limit, available metals, amendments.
\end{abstract}

\section{Introduction}

Coal based thermal power plants generate fly ash (FA) as the main industrial waste product, approximately $70-75 \%$ (Belyaeva and Haynes, 2012) and it has been recognized as an environmental hazard across the globe. India ranks third among the list of countries which generate high amount of FA, namely China, United States, Europe, South Africa, Australia, Japan, Italy, and Greece (Ram et al., 2008). The total capacity of TPPs in India had been $110232 \mathrm{MW}$ at the end of 2012 and it has been estimated that an extra capacity of $53400 \mathrm{MW}$ is likely to be added by 2017. Conceding the fact that $1 \mathrm{MW}$ thermal power results in production of $1800 \mathrm{t}$ of ash FA generation is likely to surpass 300mt by the year 2017 (end of 12th plan). In this context moderate utilization of FA has been marked by various industries while the rest is disposed on sites (landfills, FA basins and abandoned mines near TPPs) encroaching a land area of more than $40000 \mathrm{Ha}$ (Jain and Gaggar, 2013). Moreover disposal in slurry form requires 1040 $\mathrm{Mm}^{3}$ of water annually which is an extra consumption of water resources (Paliwal, 2013). This dumping activity has deleterious effects and contaminates nearby aquatic and terrestrial ecosystems. During summers, strong winds lead to blowing of fine FA 
particles into atmosphere over long distances causing health hazards. Air blown particles $<10 \mu \mathrm{m}$ size remain suspended in the air for a long time often leading to atmosphere invisibility. Local people residing in nearby villages of the thermal power plants have been found to suffer from cancer, heart disease, genetic and respiratory disorders (USEPA, 2007). Moreover, Bryan et al. (2012) studied the effects of FA on birds nesting around coal FA basins and observed adverse results due to accumulation of Se, As, Cd, and $\mathrm{Sr}$ in their offspring.

FA management is therefore an important environmental perspective which requires management of mainly 4 aspects: (1) a safe FA disposal method (2) land requirement (3) control of air pollution by suspended particulate matter and (4) control of soil and water pollution through curbing movement of heavy metals into ground water and through food chain. The third and fourth constraints can be managed through vegetation establishment. Phytomanagement is the most cost-effective and eco-friendly approach as it would stabilize the ash dumps, oversight wind and water erosion and incur gradual restoration of the site. Several other functions include reduction in leaching of water and solutes, stabilization or bioaccumulation of metals, carbon sequestration in ash soil-plant system and creation of shelter for wildlife. Furthermore proper rehabilitation programmes also serve the purpose of generation of bio-resource for local villagers and thus elevate their socio-economic status. Thirdly these would help in buildup of an aesthetically pleasing landscape and places for tourist attraction (Belyaeva and Haynes, 2012; Pandey, 2012b). In a nutshell, an engineered sustainable ecosystem can be developed with the help of tolerant plant species which would also alleviate the problems.

The initial cover development is generally done by establishment of grasses and legumes. Grass-legume cover has become the most efficient choice as they can readily colonize the area and develop a thick vegetation mat in a short period of time. Consecutively it enhances, fertility of the area, curtail erosion, air pollution and also phytoremediates the metal contaminated substrate. This paves the pathway for future long term management and gradual restoration of the site. Inspite of this choice, revegetation of existent abandoned fly ash dumps, landfills and also those which are being created require prior consideration of various factors. These are the characteristics of the material, its effect on the nearby ecosystem and probable future effects. This paper addresses all these crucial issues which should be considered before revegetation. Further, retrospection of the earlier studies done here will also enlighten the research needs and paradigms which should be focused. A special emphasis has been given to the bioaccumulation of metals by the various plant species and various indexes to conjecture metal pollution level. Conglomeration of all this information in this paper would help in selection of the best strategy for restoration of fly ash dumps for long term management.

\section{Fly ash utilization and disposal}

The high rate of FA generation in India is due to the fact that Indian coal has very high ash content (35-45\%) and is of lower quality (Mathur et al., 2003). Albeit thermal power producers are now exploring methods for $100 \%$ FA utilization, a target set by environment ministry, but with a slow success according to a report by Central Electricity Authority, 2012. 163.56 million ton of ash was produced in India in the year 2012-13 and corresponding utilization amounted to 63\% which is 
branched in cement sector $(41.33 \%)$, reclamation of low lying areas $(11.83 \%)$, roads and embankments (6.02\%), mine filling (10.34\%), bricks and tiles (9.98\%), agriculture $(2.5 \%)$, and others $(6.41 \%$ ) (Figure 1) (Central Electricity Authority, 2012). FA has been extensively used as amendments in agricultural soils to boost crop growth and yield for example in Lettuce (Lau and Wong, 2001); Zea mays, Medicago sativa, Phaseolus vulgaris (Wong and Wong, 1989); Brassica parachinensis and Brassica chinensis (Wong and Wong, 1990); Brassica oleracea (Kim et al., 1997); Brassica campestris (Jayasinghe and Tokashiki, 2012); Oryza sativa (Lee et al., 2006) and many more. Nevertheless, utilization of FA for agricultural purposes is not always beneficial for crops. Further in a study carried by Singh et al., 2008 it was recommended not to grow green leafy vegetables with FA as an amendment. In the experiment it was observed that metal pollution index (MPI) of both roots and shoots of $B$. vulgaris plants was showing significant negative relationships with the yield. Although earlier reports show that small application of FA as amendment can bring success and proves it as an efficient additive but the carryover of toxic metals from FA to plants may produce hazardous effects in the long run or in future and also in the higher trophic levels of the food chain (Singh et al., 2008). Therefore use of FA in agriculture has to take into account the possible toxic effects of toxic heavy metals which may be present. As per the data acquired, country wise FA generation and utilization of 5 nations in the world scenario is also shown in Figure 2 (Ram and Masto, 2014). The worldwide average utilization of FA is only about $25 \%$ (Wang, 2008). A huge amount of FA, approximately 63 million tonnes was dumped in India even after its utilization in major sectors (Central Electricity Authority, 2012). FA is disposed off in two ways, i.e. dry disposal in ash mounds and wet disposal in ash ponds in the form of slurry. Dry disposal incurs air pollution by blowing of fine particles by wind. It has also been reported that power plants are missing the mark of proper disposal of FA as stated by the ministry (Central Electricity Authority, 2012).

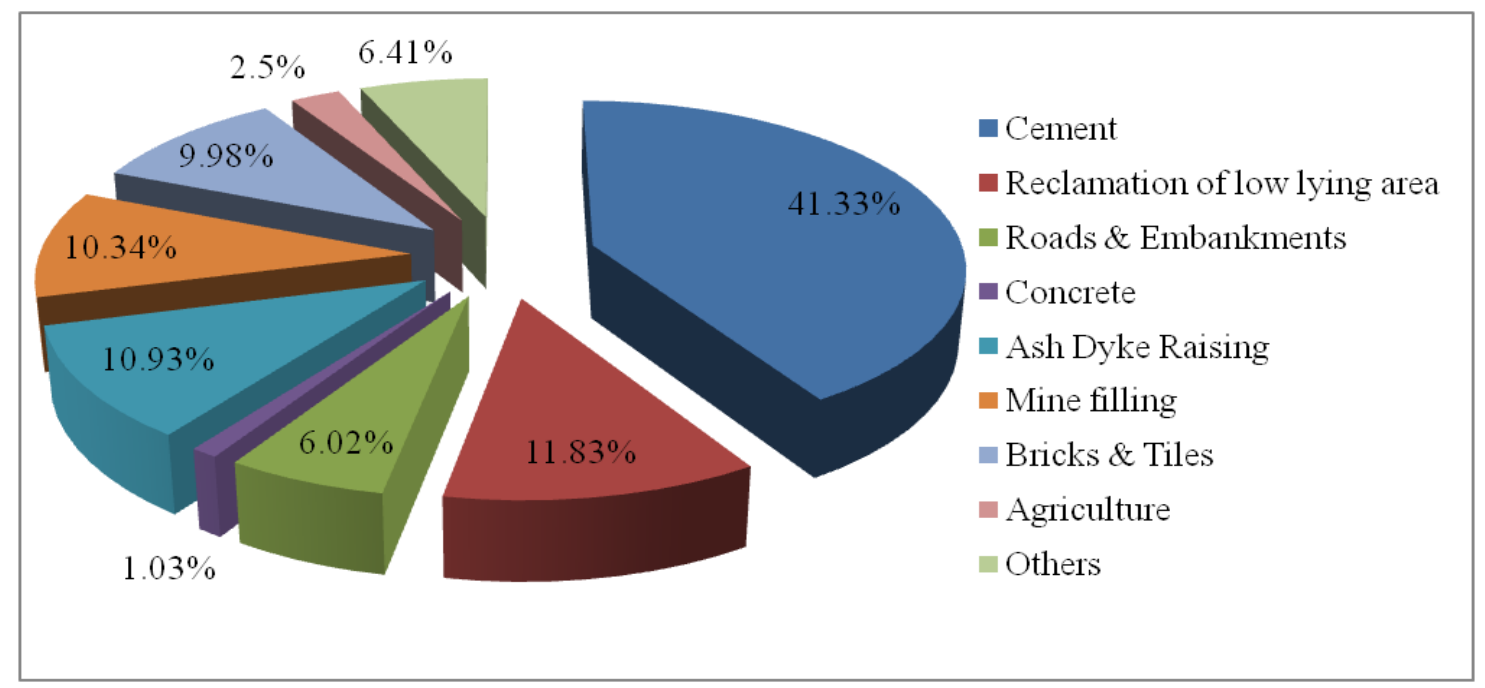

Figure 1. Fly ash utilization in Indian scenario, in different sectors/industries in the year 20122013. Modified from Central Electricity Authority, 2012. 
From all these information it is evident that a major part of the FA is unutilized and needs urgent strategies for potential utilization. FA utilization in backfilling would be of some help in this case but is still in infancy. The next major area for FA utilization apart from construction is in biomass production which covers agriculture, forestry, and floriculture. FA has been used as an amendment for clay soil (Adriano et al., 1980) while alkaline type of FA has proven to be useful in agriculture for neutralizing acidic soils (Taylor and Schuman, 1988) thus facilitating revegetation of degraded lands. Very few economically important trees such as pulp and paper tree, biodiesel crops, firewood, timber wood and plywood trees are being grown in forestry. There are several issues responsible for mismanagement in utilization of FA, which includes lack of awareness, regulation, and easy availability of land. Thus a challenge stands at the forefront towards a sound management of FA and its utilization as it will save precious topsoil; reduce land requirement, degradation, and water consumption as well as quality.

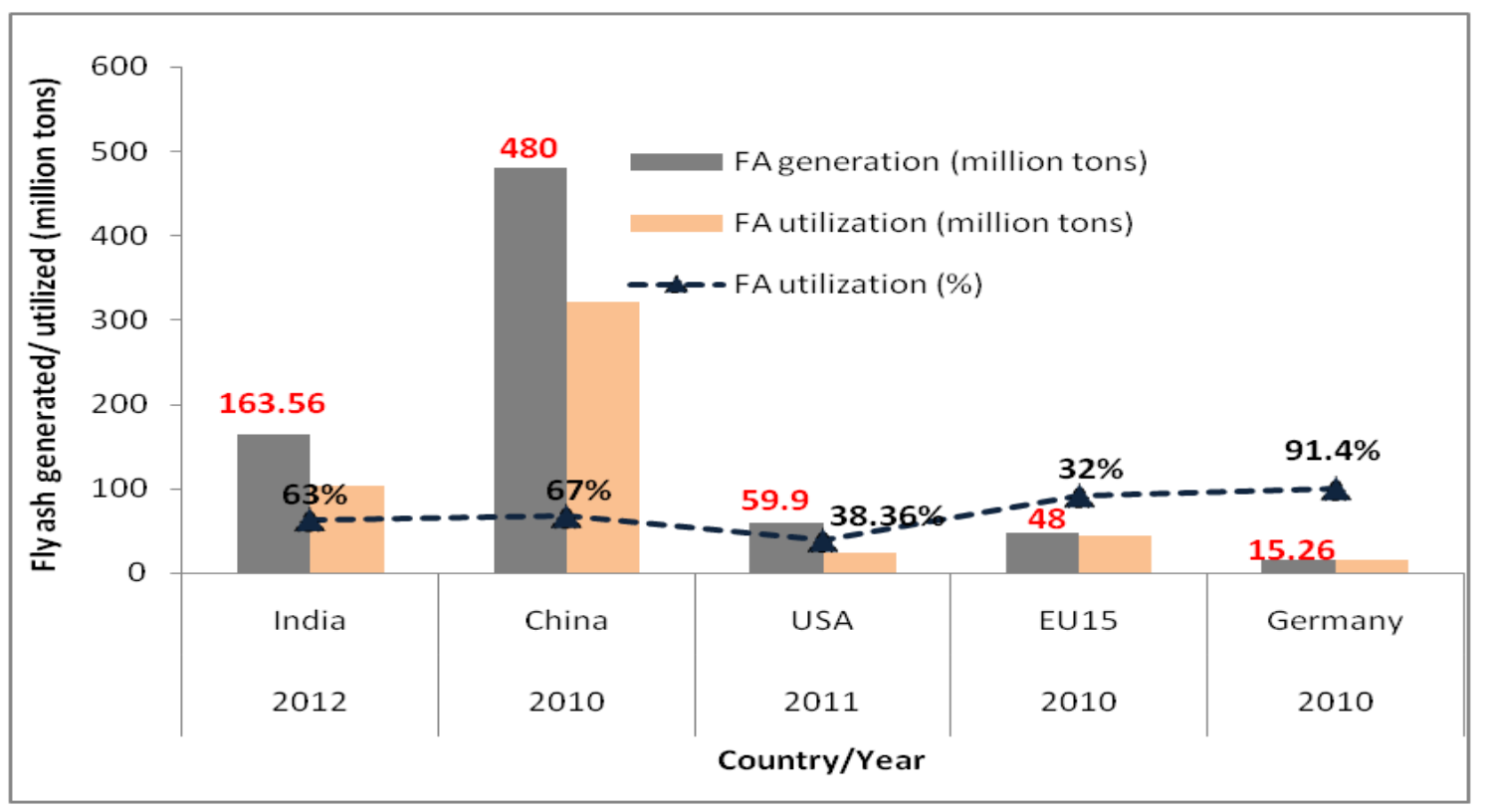

Figure 2. Fly ash generation and utilization in different countries in the world. Modified from Ram and Masto, 2014.

\section{Fly ash characteristics and constraints in vegetation establishment}

\section{Physico-chemical properties}

The prevalent factors which influence mineralogical, physical and chemical properties of FA are nature of parent coal, the conditions of combustion, type of emission control devices and storage or handling methods. Higher temperature during combustion may lead to volatilization of many mineral elements. FA is generally a residue after burning of coal and also enters flue gas stream. It consists of glass-like spherical particles ranging in size from 0.01 to $100 \mathrm{~mm}$ (Pandey et al., 2009b) which can be easily airborne (El-Mogazi et al., 1988). Some physical properties of FA are shown in Table 1 and have been compared to the natural soil. The glass-like spherical particles are hollow spheres called cenospheres, as shown in Figure 3 and may be filled with smaller amorphous crystals called pelospheres. Some authors have also considered 
FA to be predominantly composed of ferroaluminosilicate elements containing both amorphous and crystalline phases. The smaller particle size increases the specific surface area in the range from $2500-4000 \mathrm{~cm}^{2} \mathrm{~g}^{-1}$, (Alonso and Wesche, 1991) which further explains its high sorption capacity. Therefore FA is used as a sorbent to clean flue gas of SOx, NOx, toluene vapors and wastewater of $\mathrm{Cu}, \mathrm{Pb}, \mathrm{Cd}, \mathrm{Ni}, \mathrm{Zn}, \mathrm{Cr}, \mathrm{Hg}, \mathrm{As}$, Cs, F, B, dyes and pigments (El-Mogazi et al., 1988). Various studies done in literature have also shown the capability of FA to be used as zeolite for treatment of metal contaminated water (Prasad and Mortimer, 2011). Specific gravity of FA ranges from $2.1-2.6 \mathrm{~g} \mathrm{~cm}^{-3}$ and has a low to medium bulk density. It is generally observed to be whitish or yellow-orange to deep red or black-grey in color which depends on iron oxide and carbon contents. LOI (loss on ignition) can range from 0.5 to $12 \%$ which corresponds to the unburnt coal content in FA (Alonso and Wesche, 1991). FA is generally of silt loam texture (Nyambura et al., 2011) and is of finer quality if produced from bituminous coal when compared to lignite coal. Size of particles present in FA also impacts its chemical composition which generally contains oxides, hydroxides, carbonates, silicates, and sulfates of calcium, iron, aluminium, and other metals in trace amounts (Adriano et al., 1980) (Table 2).

Table 1. Physical properties of fly ash and natural soil.

\begin{tabular}{|l|l|l|}
\hline Parameters & Fly ash $^{\mathbf{a}}$ & Soil $^{\mathbf{b}}$ \\
\hline Particle diameter & $0.01-100 \mu \mathrm{m}$ & - \\
\hline Texture & Silt loam & Sandy-clayey-silty loam \\
\hline Specific surface area & 2500 to $4000 \mathrm{~cm}^{2} \mathrm{~g}^{-1}$ & - \\
\hline Specific gravity & $1.6-2.6 \mathrm{~g} \mathrm{~cm}^{-3}$ & $2.5-2.8 \mathrm{~g} \mathrm{~cm}^{-3}$ \\
\hline Bulk density & $0.9-1.3 \mathrm{~g} \mathrm{~cm}^{-3}$ & $1.3-1.8 \mathrm{~g} \mathrm{~cm}^{-3}$ \\
\hline Water holding capacity & $40-60 \%$ & $40 \%$ \\
\hline Color & White/yellow-orange/black & Yellow/orange-brown/black \\
\hline
\end{tabular}

${ }^{a}$ El-Mogazi et al., 1988; Nyambura et al., 2011; Alonso and Wesche, 1991

${ }^{\mathrm{b}}$ Kabata-Pendias and Sadurski (2004)

Table 2. Chemical properties of FA from lignite, bituminous as well as anthracite coal (Ram and Masto, 2010).

\begin{tabular}{|c|c|c|c|}
\hline Parameters & Lignite ash & Bituminous/sub bituminous ash & Anthracite ash \\
\hline pH & 11.00 & $4.50-11.0$ & 4.5 \\
\hline $\mathrm{SiO}_{2}(\%)$ & $48.40 \pm 0.99$ & $38.0-63.0$ & $51.7-54.4$ \\
\hline $\mathrm{Al}_{2} \mathrm{O}_{3}(\%)$ & $29.80 \pm 0.81$ & $27.0-44.0$ & $21.5-23.8$ \\
\hline $\mathrm{Fe}_{2} \mathrm{O}_{3}(\%)$ & $5.40 \pm 0.68$ & $3.3-6.4$ & $6.09-7.18$ \\
\hline $\mathrm{CaO}(\%)$ & $7.90 \pm 0.53$ & $0.2-0.8$ & $0.29-0.47$ \\
\hline $\operatorname{MgO}(\%)$ & $2.60 \pm 0.30$ & $0.01-0.5$ & $0.92-1.18$ \\
\hline $\mathbf{K}_{2} \mathbf{O}(\%)$ & $0.20 \pm 0.02$ & $0.04-0.9$ & $2.80-2.99$ \\
\hline $\mathrm{Na}_{2} \mathrm{O}(\%)$ & $0.40 \pm 0.03$ & $0.07-0.43$ & $0.22-0.35$ \\
\hline $\mathrm{SO}_{3}(\%)$ & $2.80 \pm 0.22$ & $0.03-0.16$ & $0.05-0.27$ \\
\hline $\mathrm{P}_{2} \mathrm{O}_{5}(\%)$ & $0.40 \pm 0.03$ & - & - \\
\hline $\mathrm{TiO}_{2}(\%)$ & $1.40 \pm 0.09$ & $0.4-1.8$ & - \\
\hline LOI (\%) & $5.70 \pm 0.22$ & $0.2-3.4$ & $9.55-12.92$ \\
\hline $\mathrm{Cl}^{-}(\%)$ & 0.04 & - & - \\
\hline $\mathrm{NO}_{3}^{-}(\%)$ & 0.004 & - & - \\
\hline
\end{tabular}



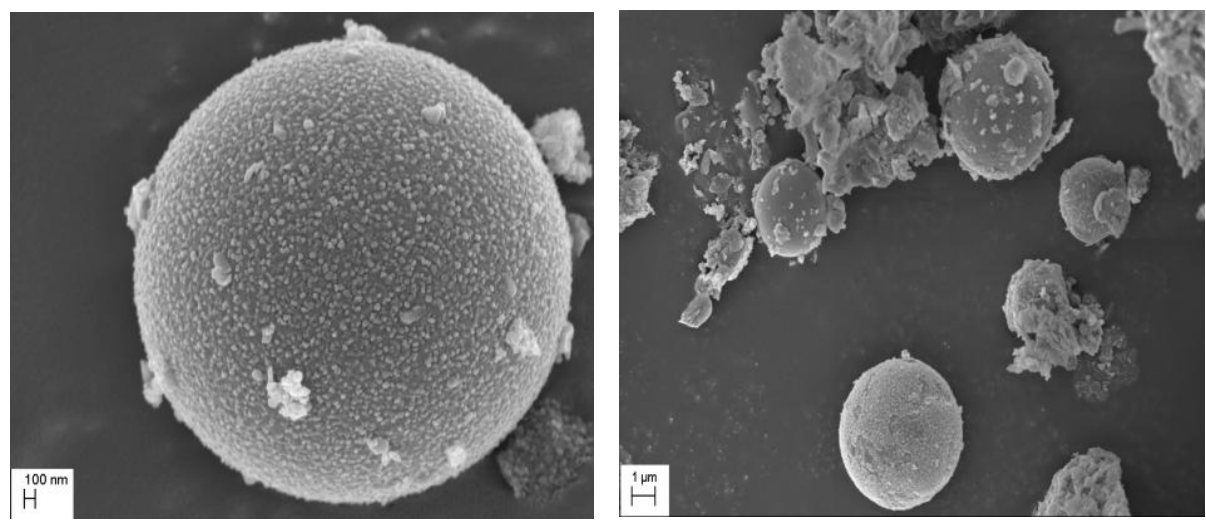

Figure 3. Cenospheres of fly ash as seen under scanning electron microscope.

The $\mathrm{pH}$ of FA varies widely from 4.5 to 11.0 and mainly depends on $\mathrm{S}$ and $\mathrm{CaO}$ content of the parent coal (Ram and Masto, 2010) (Table 2). Anthracite coals of eastern U.S. produce acidic ashes and lignite coal of western U.S. produce alkaline ashes (Page et al., 1979). It has high moisture retention capacity and low electrical conductivity (EC); and lower cation exchange capacity (CEC) than normal soil. Different types of coal such as anthracite, bituminous, sub-bituminous (class F FA containing less than 7\% $\mathrm{CaO}$, high $\mathrm{S}$, low $\mathrm{pH}$ ) and lignite (class $\mathrm{C}$ FA containing up to $30 \% \mathrm{CaO}$, low $\mathrm{S}$, high $\mathrm{pH}$ ) produce ashes of different compositions as shown in Table 2 (Wang and $\mathrm{Wu}$, 2006). XRD analysis of FA contributes direct information about the mineralogical composition of the FA sample as shown in Table 2. It is based on the principle that each crystalline compound produces a unique diffraction pattern.

Phase identifications are done by comparing the diffraction patterns to a database of pure phase reference patterns (Stutzxna and Centeno, 1995). Lignite ash has high $\mathrm{SiO}_{2}$, $\mathrm{CaO}, \mathrm{MgO}, \mathrm{Al}_{2} \mathrm{O}_{3}$, and $\mathrm{SO}_{3}$ in compared to others whereas anthracite ash has high $\mathrm{SiO}_{2}$, $\mathrm{Al}_{2} \mathrm{O}_{3}$, with a considerable amount of $\mathrm{K}_{2} \mathrm{O}$. In humid conditions weathering may take place on the stored ash in landfills or dumps and solubilise constituents which get leached (Adriano et al., 1980). Leaching of the salt compounds and metals may contimanate the ground water in a long term scenario. Therefore, disposal to ash should be accompanied by prior application of geoliners on the surface of landfills or mines.

\section{Elemental composition}

There exists a wide variation in elemental composition of fly ashes and usually contain considerable amounts of plant nutrients (such as $\mathrm{Ca}, \mathrm{K}$, and $\mathrm{Mg}$ ) when compared to soils, and as shown in Table 3. Various cations in FA are present in the form of oxides, hydroxides, carbonates and bicarbonates which dissolve at different rates (Ulery et al., 1993) and their availability depends on the $\mathrm{pH}$ of the system and its microbial activity during gradual plant growth on the substrate. Micronutrients such as $\mathrm{Cu}, \mathrm{Fe}, \mathrm{Mn}, \mathrm{Mo}, \mathrm{Zn}, \mathrm{B}$ are also present in similar quantities as in soils and constitute a considerable pool for nutrient source for plants. Phosphorus concentration in FA is quite high compared to soils in some cases; however it is generally present in unavailable forms which are unusable by the plant (Page et al., 1979). P mostly remains occluded in aluminosilicates or is present in the form of weakly soluble aluminum phosphate (Erich, 1991). Similarly, FA also lacks nitrogen supply which is an essential constituent for 
plant growth. Tripathi et al., 2008 showed the presence of $0.676 \%$ total nitrogen in FA when compared to soil which had $1.2 \%$ nitrogen. Initial establishment of vegetation on FA sites would require high rate of fertilizer application. During gradual succession of vegetation the available nitrogen in the FA landfills increase at a steady rate. This has also been reported in various studies (Pandey et al., 2014, 2015).

Besides micronutrients various toxic metals such as $\mathrm{Cd}, \mathrm{Pb}, \mathrm{Ni}, \mathrm{Se}$, and $\mathrm{Hg}$ are also present in FA and may enter food chain through vegetable crops growing on it. A study by Patra et al., 2012a through particle induced X-ray emission spectroscopic technique confirmed that $\mathrm{K}, \mathrm{Ca}, \mathrm{Ti}, \mathrm{Fe}$ are present as major elements in FA samples while $\mathrm{V}, \mathrm{Cr}$, $\mathrm{Mn}, \mathrm{Co}, \mathrm{Ni}, \mathrm{Cu}, \mathrm{Zn}, \mathrm{As}, \mathrm{Se}, \mathrm{Rb}, \mathrm{Sr}$ and $\mathrm{Pb}$ are present in trace amounts. Dumping of FA on land contaminates soil and water through the presence of potentially toxic elements mostly in water soluble form. High levels of $\mathrm{pH}$ and toxic metals, lack of microbial activity as well as natural compaction of FA particles inhibits water infiltration and root growth and this restricts vegetation establishment to some extent (Haynes, 2009). Heavy metals induce oxidative stress within plant systems leading to production of reactive oxygen species (ROS) such as superoxide radicals $\left(\mathrm{O}_{2}{ }^{\circ}\right)$, hydroxyl radicals $\left({ }^{\circ} \mathrm{OH}\right)$ and hydrogen peroxide $\left(\mathrm{H}_{2} \mathrm{O}_{2}\right)$. These ROS readily react with lipids and proteins leading to cellular damage (Pandey et al., 2010; Sinha and Gupta, 2005). Plants can also encounter ROS through various enzymatic and non-enzymatic defense systems which involve production of cysteine (Grill et al., 1991). Revegetation with efficient FA tolerant plants ensures faster stabilization of the area. Plant tolerance to these stresses can be examined through analysis of a group of enzymes or compounds and thus candidate species for the phytoremediation of FA landfills can be identified.

\section{Plant species used for revegetation}

Establishment of a vegetation cover on FA basins helps to increase organic matter content of the substrate through inputs of litter and fine roots. Organic matter is further decomposed and mineralized by microbial communities through enzyme activities and this regulates nutrient cycling.

\section{Fly ash tolerant, native and non-native species}

Rehabilitation programmes should be designed in such a way to conjointly incur both ecological restoration of sites and also involve significant economical outputs. This can be done through an effective eco- engineering technology which would constitute the selection of both native invaders and economically useful species as primary and secondary colonizers. Natural succession on FA basins at regional scale has been studied at different parts of the world. Native species have inherent adaptability to resist adverse conditions, increase soil fertility, have faster establishment and provide a sustainable micro-climate for establishment of commercially useful species. This in turn brings out an economical value from the rehabilitation programs (Pandey and Singh, 2011). Recently, Pandey et al., 2014 and Zolnierz et al., 2016 have enumerated various naturally growing species on FA deposits at during initial colonisation and 11 years after vegetation establishment. Some examples of naturally growing species are Saccharum munja (Pandey et al., 2012); non-nodulated species Cassia siamea Lamk; nodulated species of chickpea (Pandey et al., 2010) and Pteris vittata weredone, a fern, (Srivastava et al., 2005). S. munja has been called as an "ecological engineer" due to properties such as; firm ash-soil binding capability and stabilizes the ash dump surface. 
This indirectly controls suspended particulate matter generation in the air. It is also useful in various rural applications and is thus economically viable. Some naturally colonizing species over FA dump and those used for pot scale studies along with their metal accumulation tendencies has been enumerated in Table 4. Pandey (2013) suggested Ricinus communis L., naturally growing on FA land fill sites to be a suitable plant species for revegetation in tropical and sub-tropical regions. Apart from being an industrially valuable oil yielding crop, it has the properties of metal accumulation and stabilization in root parts. Moreover it is unpalatable in nature and also provides benefits such as carbon sequestration, substrate quality enhancement, aesthetically pleasant landscape, and biodiversity conservation. Ferns like P.vittata L., Ampelopteris prolifera (Retz.) Copel., Diplazium esculentum (Retz.) Sw. and Thelypteris dentata (Forsk.) E. St. John also grow well on FA and does not show toxicity symptoms from heavy metals which is unavoidable in case of crop plants (Haynes, 2009). Kumari et al., 2013 reported that the fern $T$. dentata has high tolerance potential against heavy metals in FA and can be used efficiently to revegetate/stabilize FA landfills.

Studies have been carried out to revegetate FA disposal sites with tree species selected on the basis of economic importance which would fulfill wood demands of forest based industries. Leucaena leucocephala, Dendrocalamus strictus and Eucalyptus sp. established on FA dumpsites may be used in pulp and paper industry (Pandey et al., 2009b). Some timber and plywood yielding plants have also been used successfully in studies are Shorea robusta, Tectona grandis, D. sissoo, Bombex ceiba, Populus euphratica and Eucalyptus tereticornis (Juwarkar and Jambhulkar, 2008; Ram et al., 2008). Fuel wood tree species recommended by some workers, such as Albizia lebbek, Acacia auriculiformis, Acacia nilotica, Casuarina equisetifolia, Cassia siamea, Prosopis juliflora and Dalbergia sissoo have nitrogen fixing characteristics, excellent growth characteristics in nutrient poor conditions in addition to their economic importance. Trees which yield both fuel as well plywood are Tamarindus indica, Melia azedarach, Populus deltoides, Eucalyptus hybrid, Eucalyptus globulus and Syzigium cumini (Pandey et al., 2009b). In a study by Carlson and Adriano (1991) it was depicted that a new ecosystem can been created on alkaline and acidic FA dump sites with Platanus occidentalis (Sycamore) and Liquidambar styraciflua, (Sweetgum) which are important timber trees. Gradual development of a productive forest ecosystem also provides habitat for biotic communities, establishes food-chain trophic levels and biogeochemical cycles. Despite of the useful properties of this tree species initial establishment in the harsh conditions of fly ash is a tedious process. Therefore, strategies such as additions of amendments, spreading of grass legume fodder seeds, forage legumes, tuft or hardy grasses are an efficient choice.

They help in development of a vegetation mat in a small period of time when compared to the tree species. Moreover, a reclaimed site can then be used as per the destined land use. 
Table 3. Ranges in elemental composition of fly ash, soil, farm yard manure, plants in India and worldwide along with maximum allowable concentrations (MAC) for trace metals in soils and plants.

\begin{tabular}{|c|c|c|c|c|c|c|c|c|c|}
\hline \multirow{3}{*}{$\begin{array}{l}\text { Metals } \\
\left(\mathrm{mg} \mathrm{kg}^{-1}\right)\end{array}$} & \multirow[t]{3}{*}{ Soil $^{\mathrm{a}}$} & \multicolumn{4}{|c|}{ Fly ah } & \multirow[t]{3}{*}{ FYM $^{d}$} & \multirow[t]{3}{*}{$\mathrm{MAC}^{\mathrm{e}}$} & \multirow[t]{3}{*}{ Plants $^{f}$} & \multirow{3}{*}{$\begin{array}{l}\text { MAC for } \\
\text { plants }\end{array}$} \\
\hline & & \multirow[t]{2}{*}{ Range $^{\mathrm{a}}$} & \multicolumn{2}{|c|}{ India $^{b}$} & \multirow[t]{2}{*}{ Worldwide $^{c}$} & & & & \\
\hline & & & Total & Available & & & & & \\
\hline $\mathbf{F e}$ & $7-550$ & $10-290$ & 68 & $10-15$ & $0.31-36.6$ & 3040 & - & - & - \\
\hline Al & $40-300$ & $1-17.3$ & $4.8-312$ & $0.1-822$ & $0.5-108.5$ & - & - & - & - \\
\hline $\mathbf{C a}$ & $7-500$ & $1.1-222$ & $0.029-34$ & $460-4400$ & $1.84-86.4$ & - & - & - & - \\
\hline Mg & $0.6-6$ & $0.4-76$ & $0.017-1.4$ & $0.8-179$ & $0.02-11.5$ & - & - & - & - \\
\hline $\mathbf{K}$ & $0.4-30$ & $1.5-35$ & 10.8 & $32-8900$ & 24.5 & - & - & - & - \\
\hline B & $2-100$ & $10-618$ & $17-38$ & $0.5-3$ & $0.4-50$ & 52 & - & - & - \\
\hline Mn & $100-4000$ & $58-3000$ & $500-739$ & $0.9-19$ & $100-679$ & 53.1 & $1500-3000$ & $20-1000$ & $300-500$ \\
\hline $\mathbf{P}$ & $0.05-2$ & $0.4-8$ & 10.8 & 6.2 & 2.1 & 24 & - & - & - \\
\hline Co & $1-40$ & $7-520$ & $21.1-58$ & $0.05-0.15$ & $7-26$ & 0.85 & $20-50$ & $0.02-1$ & $15-50$ \\
\hline $\mathbf{C u}$ & $2-100$ & $14-2800$ & $40-80$ & $0.5-11$ & $19-57$ & 44.1 & $60-150$ & $5-20$ & $2-100$ \\
\hline $\mathbf{Z n}$ & $10-300$ & $10-3500$ & $52-203$ & $0.4-4.6$ & $39-167$ & 24.7 & $100-300$ & $1-400$ & $100-400$ \\
\hline Mo & $0.2-5.0$ & $7-160$ & $4.0-33.3$ & $0.1-0.6$ & $3-4.2$ & 4.5 & $4-40$ & $0.03-5$ & $10-50$ \\
\hline $\mathbf{N i}$ & $10-1000$ & $6-4300$ & $50-204.8$ & $0.15-3$ & $15-88$ & 39.4 & $20-60$ & $0.02-5$ & $10-100$ \\
\hline Se & $0.1-2$ & $0.2-134$ & $0.6-2.6$ & $0.1-0.4$ & $8-10$ & 0.56 & $3-10$ & $0.001-2$ & $5-30$ \\
\hline As & $0.1-40$ & $2-6300$ & $1-4$ & $0.1-16$ & 20.4 & 0.62 & $15-20$ & $0.02-7$ & $5-20$ \\
\hline $\mathbf{C d}$ & $0.01-0.5$ & $0.7-130$ & $5-43$ & $0.03-0.07$ & $0.03-1.3$ & $<0.002$ & $1-5$ & $0.1-2.4$ & $5-30$ \\
\hline $\mathrm{Cr}$ & $5-3000$ & $10-1000$ & $38.2-330$ & $0.3-1.3$ & $15-148$ & $<0.002$ & $3-25$ & $0.03-14$ & $5-30$ \\
\hline $\mathbf{H g}$ & Up to 1 & $0.02-1.0$ & BDL & BDL & $0.18-0.4$ & $<0.001$ & $0.5-5$ & $0.005-0.17$ & $1-3$ \\
\hline $\mathbf{P b}$ & $2-100$ & $3-5000$ & $20-70$ & $<0.1$ & $16-97$ & $<0.002$ & $20-300$ & $0.2-20$ & $30-300$ \\
\hline
\end{tabular}

-: Not available, FYM: farmyard manure; BDL: below detection limit,

${ }^{\mathrm{a}}$ Page et al., 1979, ${ }^{\mathrm{b}}$ Pandey et al., 2009, ${ }^{\mathrm{c}}$ Adriano et al., 1980, ${ }^{\mathrm{d}}$ Tripathi et al., 2004, ${ }^{\mathrm{e}}$ Kabata-Pendias and Sadurski (2004), ${ }^{\mathrm{f}}$ Alloway, 2013. 
Table 4. List of plant species found growing efficiently on fly ash dumpsites as well pot studies alongwith the detailed description of the, BAF, BCF and TFs.

\begin{tabular}{|c|c|c|c|c|c|c|c|}
\hline Species & Place & $\begin{array}{l}\text { Native/ } \\
\text { introduced }\end{array}$ & $\begin{array}{l}\text { Metals studied } \\
\text { and technology } \\
\text { involved }\end{array}$ & $\begin{array}{l}\text { Experimental } \\
\text { setup/ treatment } \\
\text { used }\end{array}$ & $\begin{array}{l}\text { Periods } \\
\text { of plant } \\
\text { harvest }\end{array}$ & $\begin{array}{l}\text { Plant part and } \\
\text { bioacccumulation of } \\
\text { metals }\end{array}$ & Reference \\
\hline T. dentata & $\begin{array}{l}\text { Lucknow } \\
\text { UP, India }\end{array}$ & Native fern & $\begin{array}{l}\mathrm{Fe}, \mathrm{Si}, \mathrm{As}, \mathrm{Cd}, \\
\mathrm{Pb} ; \\
\text { phytostabilization }\end{array}$ & $\begin{array}{l}\text { Grown in pots } \\
25,50,75 \text { and } \\
100 \% \text { FA } \\
\text { treatments }\end{array}$ & $\begin{array}{l}30 \text { and } \\
45 \text { days }\end{array}$ & $\begin{array}{l}\text { BAF values of } \mathrm{Si}, \mathrm{As}, \mathrm{Cd} \\
\text { and } \mathrm{Pb} \text { was }>1 ; \mathrm{TF}<1 \\
\text { except for } \mathrm{Pb}(1.16) \text { and } \\
\mathrm{As}(1.07) \text { in } \\
25 \% \text { and } 100 \% \mathrm{FA} \\
\text { respectively }\end{array}$ & $\begin{array}{l}\text { Kumari et } \\
\text { al., } 2013\end{array}$ \\
\hline R. communis L. & India & $\begin{array}{l}\text { Native, } \\
\text { Bio-energy } \\
\text { crop }\end{array}$ & $\begin{array}{l}\mathrm{Cu}, \mathrm{Ni}, \mathrm{Zn}, \mathrm{Cd}, \\
\mathrm{Pb} ; \\
\text { phytostabilization }\end{array}$ & $\begin{array}{l}\text { Growing } \\
\text { naturally in FA } \\
\text { landfill sites }\end{array}$ & - & Conc in $\mathrm{R}>\mathrm{S}$ & $\begin{array}{l}\text { Pandey, } \\
2013\end{array}$ \\
\hline S. munja & $\begin{array}{l}\text { Uttar } \\
\text { Pradesh, } \\
\text { India }\end{array}$ & $\begin{array}{l}\text { Native } \\
\text { grass }\end{array}$ & $\begin{array}{l}\mathrm{Fe}, \mathrm{Cd}, \mathrm{Cr}, \mathrm{Cu} \text {, } \\
\mathrm{Mn}, \mathrm{Ni}, \mathrm{Pb}, \mathrm{Zn} ; \\
\text { phytostabilization } \\
\text { and } \\
\text { phytoextraction } \\
\text { for } \mathrm{Fe}, \mathrm{Mn}\end{array}$ & $\begin{array}{l}\text { Growing } \\
\text { naturally in FA } \\
\text { lagoons }\end{array}$ & - & $\begin{array}{l}\text { All BAF values in } \mathrm{R} \text { and } \\
\mathrm{L}<1 \text { (excluder species); TF } \\
=0.6-1.52 \text { except } \mathrm{Mn}, \mathrm{Fe} \text {; } \\
\text { excluding order }= \\
\mathrm{Zn}>\mathrm{Cd}>\mathrm{Cr}>\mathrm{Ni}>\mathrm{Pb}>\mathrm{Cu}\end{array}$ & $\begin{array}{ll}\text { Pandey et } \\
\text { al., } 2012\end{array}$ \\
\hline Azolla caroliniana & $\begin{array}{l}\text { Uttar } \\
\text { Pradesh, } \\
\text { India } \\
\end{array}$ & Native fern & $\begin{array}{l}\mathrm{Cu}, \mathrm{Pb}, \mathrm{Mn}, \mathrm{Ni}, \\
\mathrm{Zn}, \mathrm{Cr}, \mathrm{Cd}, \mathrm{Fe} ; \\
\text { phytostabilization }\end{array}$ & $\begin{array}{l}\text { Ferns growing } \\
\text { naturally on FA } \\
\text { ponds }\end{array}$ & - & $\begin{array}{l}\text { Metal in } \mathrm{R} \text { were } 175 \text { to } 538 \\
\mathrm{mg} \mathrm{kg}^{-1} \text { and in } \mathrm{S} \text { was } 86 \text { to } \\
753 \mathrm{mg} \mathrm{kg}^{-1}\end{array}$ & $\begin{array}{l}\text { Pandey, } \\
2012 \mathrm{a}\end{array}$ \\
\hline I. carnea & $\begin{array}{l}\text { Uttar } \\
\text { Pradesh, } \\
\text { India }\end{array}$ & Invasive & $\begin{array}{l}\mathrm{Cd}, \mathrm{Pb}, \mathrm{Cu}, \mathrm{Cr}, \\
\mathrm{Mn} \mathrm{and} \mathrm{Ni} \text {; } \\
\text { phytoextraction } \\
\text { for } \mathrm{Cd}, \mathrm{Cr} \text { and } \\
\text { phytostabilization } \\
\text { for other metals }\end{array}$ & $\begin{array}{l}\text { Naturally grown } \\
\text { on FA deposits }\end{array}$ & - & $\begin{array}{l}\text { BCF values of } \mathrm{Cd}, \mathrm{Pb}, \mathrm{Mn} \text {, } \\
\text { and } \mathrm{Ni} \text { in } \mathrm{R} \text { and } \mathrm{S} \text { were }>1 \text {; } \\
\mathrm{TF} \text { for } \mathrm{Cd} \text { and } \mathrm{Cr}>1\end{array}$ & $\begin{array}{l}\text { Pandey, } \\
2012 b\end{array}$ \\
\hline S. virgata & $\begin{array}{l}\text { Argentinean } \\
\text { Pampas }\end{array}$ & Native & $\begin{array}{l}\mathrm{Cu}, \quad \mathrm{Zn}, \quad \mathrm{Cr} ; \\
\text { phytostabilization }\end{array}$ & $\begin{array}{l}\text { Pot } \\
\text { experiment, } \mathrm{Cu} \text {, } \\
\mathrm{Zn}, \mathrm{Cr} \text { added }\end{array}$ & - & $\begin{array}{l}\text { Conc in } \mathrm{R}>\mathrm{S} \text {; } \mathrm{BCF} \text { was in } \\
\text { order } \mathrm{Zn}>\mathrm{Cr}>\mathrm{Cu}\end{array}$ & $\begin{array}{l}\text { Branzini et } \\
\text { al., } 2012\end{array}$ \\
\hline
\end{tabular}




\begin{tabular}{|c|c|c|c|c|c|c|c|}
\hline & & & & $\begin{array}{l}\text { individually and } \\
\text { in binary } \\
\text { mixtures }\end{array}$ & & & \\
\hline $\begin{array}{l}\text { A. indica, } \\
\text { C. siamea, } \\
\text { E. hybrida, } \\
\text { E. officinalis, } \\
\text { T. grandis, D.strictus, } \\
\text { D. sissoo } \\
\text { P. pinnata }\end{array}$ & $\begin{array}{l}\text { Khaperkhed } \\
\text { a thermal } \\
\text { power } \\
\text { plant, } \\
\text { Nagpur, } \\
\text { India }\end{array}$ & Native & $\begin{array}{l}\mathrm{Fe}, \mathrm{Mn}, \mathrm{Ni}, \mathrm{Zn} \text {, } \\
\mathrm{Cu}, \mathrm{Cr}, \mathrm{Pb} ; \mathrm{C} \\
\text { siamea has been } \\
\text { found as a } \\
\text { hyperaccumulator }\end{array}$ & $\begin{array}{l}\text { Field } \\
\text { experiment (10 } \\
\text { ha) FA dump } \\
\text { with organic } \\
\text { amendments } \\
\text { and } \\
\text { biofertilizers }\end{array}$ & - & $\begin{array}{l}\text { BCF was in order } \\
\mathrm{Fe}>\mathrm{Mn}>\mathrm{Ni}>\mathrm{Zn}>\mathrm{Cu}>\mathrm{Cr}>\mathrm{P} \\
\mathrm{b} ;\end{array}$ & $\begin{array}{l}\text { Jambhulkar } \\
\text { and } \\
\text { Juwarkar, } \\
2009\end{array}$ \\
\hline S. cannabina & $\begin{array}{l}\text { Uttar } \\
\text { Pradesh, } \\
\text { India }\end{array}$ & $\begin{array}{l}\text { Green } \\
\text { manure } \\
\text { crop }\end{array}$ & $\begin{array}{l}\mathrm{Fe}, \mathrm{Mn}, \mathrm{Zn}, \mathrm{Cu}, \\
\mathrm{Pb}, \quad \mathrm{Ni} ; \\
\text { phytostabilization }\end{array}$ & $\begin{array}{l}\text { Pot experiment } \\
\text { with mixtures of } \\
\text { FA + GS from } \\
10-100 \%\end{array}$ & $\begin{array}{l}30 \text { and } \\
90 \text { days }\end{array}$ & $\begin{array}{l}\text { BCF of metals in order, Fe } \\
>\mathrm{Mn}>\mathrm{Zn}>\mathrm{Cu}>\mathrm{Pb}>\mathrm{Ni} \\
\text { and } \mathrm{TF}<1\end{array}$ & $\begin{array}{l}\text { Sinha and } \\
\text { Gupta., } \\
2005\end{array}$ \\
\hline P. juliflora & $\begin{array}{l}\text { Uttar } \\
\text { Pradesh, } \\
\text { India }\end{array}$ & Native tree & $\begin{array}{l}\mathrm{Fe}, \mathrm{Mn}, \mathrm{Zn}, \mathrm{Cu} \text {, } \\
\text { and } \mathrm{Cr} \text {; } \\
\text { phytostabilization }\end{array}$ & $\begin{array}{l}\text { Pot experiment } \\
\text { with mixtures of } \\
\text { FA + GS + } \\
\text { FYM + PM + } \\
\text { BGA }\end{array}$ & $\begin{array}{l}15,30 \\
\text { and } 45 \\
\text { days }\end{array}$ & $\begin{array}{l}\text { BCF was in order } \\
\mathrm{Fe}>\mathrm{Mn}>\mathrm{Cu}>\mathrm{Zn}>\mathrm{Cr} \text { in the } \\
\text { treatments. }\end{array}$ & $\begin{array}{l}\text { Rai et al., } \\
2004\end{array}$ \\
\hline Cassia seamea & $\begin{array}{l}\text { Uttar } \\
\text { Pradesh, } \\
\text { India }\end{array}$ & Native tree & $\begin{array}{l}\mathrm{Cu}, \mathrm{Zn}, \mathrm{Ni}, \mathrm{Fe} \text {; } \\
\text { phytostabilization } \\
\text { for all metals } \\
\text { except } \mathrm{Ni}\end{array}$ & $\begin{array}{l}\text { Pot experiment; } \\
\text { GS, FA, } \\
\text { FA+GS (1:1 } \\
\text { w/w }), \text { FA+FYM } \\
(1: 1 \mathrm{w} / \mathrm{w}), \text { FA + } \\
\text { PM }(1: 1 \mathrm{w} / \mathrm{w})\end{array}$ & $\begin{array}{l}20,40 \\
\text { and } 60 \\
\text { days }\end{array}$ & $\begin{array}{l}\mathrm{TF}<1 \text { for all metals except } \\
\mathrm{Ni}\end{array}$ & $\begin{array}{l}\text { Tripathi et } \\
\text { al., } 2004\end{array}$ \\
\hline
\end{tabular}

FA: fly ash, GS: garden soil, BAF: bioaccumulation factor, BCF: bioconcentration factor, TF: translocation factor, $\mathrm{E}_{\mathrm{f}}$ : enrichment factor, Root: R, Shoot/stem: S, Leaves: L conc.: concentration, Max.: maximum, Min.: minimum, FYM: farm yard manure, PM: press mud, BGA: blue green algae 


\section{Role of grasses and legumes}

Grasses are considered for initial vegetation cover as they are mostly drought tolerant and can grow in even nutrient poor conditions. Their gradual growth to develop a massive fibrous root network helps in slowing down erosion, increasing soil shear strength and conserving soil moisture (Tengbeh, 1993). Eventual drying of the vegetative shoots at the end of the life cycle, form mulches which also prevents erosion, facilitates water infiltration, improves soil moisture, ameliorates soil temperature and enhances nutrient supply. Stabilizing steep slopes by developing a grass cover is a better soil conservation practice and works faster than trees (Brindle, 2003). Aromatic grasses are a better option for in situ management of FA as they yield environmental and societal benefits. They are stress tolerant crops and can flourish in adverse conditions.

Earlier reports by several workers show that wild aromatic grasses are found to grow profusely and producing high biomass on FA disposal sites, for e.g. $S$. munja and $S$. spontaneum (Pandey et al., 2015). Roots of $S$. munja have been found to grow up to 10$15 \mathrm{ft}$ deep in FA (Pandey et al., 2012). Various other aromatic grasses like Cymbopogon martinii, Vetiveria zizanioides, Cymbopogon flexuosus and Cymbopogon winterianus can also be grown extensively on FA deposits to earn profits (Verma et al., 2014). Very few studies have been done in past on the growth of these grasses on FA except some reports which studied the growth pattern with high rate application of FYM (Kumar and Patra, 2012). The oil released from the leaves (C. flexuosus and $C$. winterianus), inflorescence ( $C$. martinii), and roots ( $V$. zizanioides) of these grasses is used in perfumery, pharmaceuticals and cosmetics. Heavy metal toxicity in the oil extracted can be avoided due to hydro distillation (Khajanchi et al., 2013). Moreover, their growth is supported due to porous nature of FA which assists better root growth. The unpalatability, minimal water requirement and perennial nature of these grasses make them more suitable to be used in restoration studies (Gupta et al., 2013).

Legumes have also been found to be very effective in the revegetating FA landfills (Jambhulkar and Juwarkar, 2009). They exhibit rapid growth as well as enhance substrate characteristics by increasing organic carbon and total nitrogen content. In this context, drought resistant, fast growing species are chosen which readily produce decomposable nutrient rich litter for soil (Madejon et al., 2006). Turnover of their fine roots as well as nodules also have dramatic effect on soil fertility (Singh et al., 2002). The amount of nitrogen $(\mathrm{N})$ fixed by a legume can be calculated by multiplying its biomass by a factor of 0.8 (Thomas et al., 1997) whereas approximately $13-682 \mathrm{~kg} \mathrm{~N}$ $\mathrm{ha}^{-1} \mathrm{yr}^{-1}$ can be fixed in a legume-grass plantation. Persistence of legumes, soil $\mathrm{N}$ status and competition with the associated grasses are the factors which influence $\mathrm{N}$ fixation in a mixed plantation. Use of $\mathrm{N}$ fertilizers as well as dry conditions favor increase in soil inorganic $\mathrm{N}$ which in turn reduce nitrogen fixation.

On the other hand, uptake of soil $\mathrm{N}$ by grass conjointly with competition from grasses increases $\mathrm{N}$ fixation by legumes (Lenka et al., 2012). Fixed $\mathrm{N}$ in the range of $3-102 \mathrm{~kg} \mathrm{~N}$ $\mathrm{ha}^{-1} \mathrm{yr}^{-1}$ is transferred from legume to grass through a complex pathway including contact between roots, mycorrhizal fungi, release of $\mathrm{N}$ in exudates and turnover of roots (Spehn et al., 2002). The amount of $\mathrm{N}$ transferred figures out to $2-26 \%$ of the total nitrogen fixed (Milcu et al., 2008). Lazzarotto et al., (2009) developed a dynamic plot-scale model (PROGRASS) with respect to parameters such as plant dry biomass yield, leaf area index, uptake of soil $\mathrm{N}$ and biological $\mathrm{N}$ fixation in a grass-clover plantation. This model simulated seasonal and inter-annual dynamics of plantation and the role of root development in lowering substrate $\mathrm{C}$ : $\mathrm{N}$ ratio and favoring carbon allocation to the shoot. Mixed plantation 
of grasses and legumes produce sufficient aboveground biomass which prevent formation of gullies during soil erosion (Maiti and Maiti, 2015; Normaniza and Barakbah, 2011) by obstructing raindrops and increasing surface roughness. Above ground prostrate parts also reduce flow velocity of water during heavy rain (Gray and Sotir, 1996). In a nutshell this mixed plantation creates $\mathrm{N}$ balance in soil. Generally, legumes can be used in combination with grasses, to revegetate FA disposal sites by the following ways (Tripathi et al., 2004):

1. Sowing of pasture legumes with grassy species as initial colonizers to cover the ash surface. This technique requires minute amounts of fertilizer input and facilitates nodulation in legumes. A similar type of revegetation strategy has also been done in a study conducted by (Maiti and Maiti, 2015).

2. Sowing of legumes with non-legumes. This technique requires high rate of fertilizer application to help the growth of non-legumes. For example application of sewage sludge can supply huge amounts of mineral N (Maiti and Maiti, 2015).

3. Seeding the site with rapidly growing tolerant grass species to cover the ground in a short period with the aids of fertilizers. The establishment of the grassy cover can be followed by growing leguminous forbs, shrubs or trees with the withdrawal of $\mathrm{N}$ fertilizers (Maiti and Maiti, 2015).

Some commonly used efficient and highly recommended legume-grass species for the above vegetation strategies are as follows (Maiti and Maiti, 2015):

Stylosanthes sp., commonly called Stylo legume, is widely grown in tropicagricultural areas with acidic soils (Liu et al., 1997), mainly as a cover crop to suppress weed growth (Ramesh et al., 1997). It restores soil fertility by establishing thick vegetation cover in a short period of time and thus considered as a pioneer crop for plantation on waste lands, mine sites as well as watersheds (Pathak et al., 2004; Maiti and Maiti, 2015). Some species such as S. humilis, yields high biomass, uptakes $\mathrm{P}$ (limiting nutrient) very efficiently from deficient soils and incurs biological nitrogen fixation (BNF) through nodules (O'Hara et al., 1988).

Crotalaria juncea L. is also an herbaceous, annual, fast growing tall legume plant which fixes nitrogen in nodules present in its long taproot system. Propagation of $C$. juncea occurs through seeds with a germination time of $2-3$ days after sowing in presence of adequate soil moisture of 6.4\% (Maiti and Maiti, 2015). A hectare land can be revegetated with $C$. juncea with approximately $5 \mathrm{~kg}$ seeds in regular spacing of $0.5 \mathrm{~m}$. The plant dies to generate a nitrogen rich litter and mulch for the substrate. Moreover the bark of the plant gives valuable fibre and is the earliest recorded fiber crops in history (Chaudhury et al., 1978). It is a pioneer species for nitrogen fixation and restoration of degraded lands as it improves soil quality, adds organic matter to soil, suppresses weeds and recycle plant nutrients. It is widely grown in the tropics as a summer cover crop and green manure because of its fast growth to produce more than 5.4 ton dry matter ha ${ }^{-1}$ and $1.1 \mathrm{~kg} \mathrm{ha}^{-1}$ nitrogen in $9-12$ weeks. Nitrogen concentration in leaves ranges between $2-$ $5 \%$ and $0.6-2 \%$ in roots and stems (Treadwell and Alligood, 2008).

Cymbopogon citratus, also called lemon grass is a tall, aromatic, perennial grass with deep roots and linear leaves (Akhila, 2010). It is propagated by planting old tillers through. Tops of well grown culms are generally harvested after 5.5 - 6.5 months after growth and cut till $20-25 \mathrm{~cm}$ above ground to divide the plant into slips containing 2-3 tillers. A single plant can produce approximately 40 - 50 tillers after 6 months. The growth of tillers begins at the apical meristem followed by production of axillary buds and subsequent emergence of new tillers. Increase in the number of tillers during the growth phase of lemon grass follows a sigmoid-shaped curve to reach a peak point after 
which tillers start to die. It is difficult to distinguish the main culms from new grown tillers when a maximum growth is reached (Linares et al., 2005). Oil extracted from lemon grass is used as an insecticide, as main constituent in perfumery, and as a raw material in the synthesis of aromatic substances. In Europe, leaves are used in tea and in Mexico, it is traditionally used as a sleep aid, tranquilizer, digestive, anti-influenza and antispasmodic (Rauber et al. 2005). It has been widely used for reclamation of degraded lands and can be used as barrier to control runoff and erosion. The root structure permits water to pass while holding soil particles (Sugumaran et al., 2005; Maiti and Maiti, 2015).

In addition, to the above advantages of grasses and legumes various studies in the past have proved the metal phytoremediation potential of these plants. Mitrovic et al., 2008 reported spontaneous colonisation of fly ash deposit by a grass Calamagrostis epigejos after 13 years. It was found to exhibit phytoextracting property towards metals such as B and As. In recent study Pandey et al., 2012 reported metal levels within the toxic limit for plants in S. munja. More studies on the phytoremediation potential of legumes and grasses growing on fly ash should be done to explore newer species for restoration of the degraded areas.

\section{Addition of amendments to fly ash for efficient establishment of plants}

FA landfill sites provide a hostile environment, unfavorable for plant growth, which can be made suitable through application of amendments. Amendments may be added into the surface layer of ash, preceding vegetation to favorably improve chemical and physical conditions of the substrate and sustain plant growth. This helps in boosting up vegetation establishment and thus support rehabilitation programmes (Haynes, 2009).

\section{Topsoil, organic and chemical amendments}

Covering of waste material with topsoil or subsoil typically of $5-10 \mathrm{~cm}$ depth has been the most successful method of restoration. Topsoiling furnishes favorable physicochemical conditions for plant growth, builds up nutrient supply and curtails detrimental toxic effects of ash. In general topsoil and FA are mixed considering their heterogeneous nature, i.e. clayey FA with sandy topsoil for much beneficial effects. This procedure has some limitations as it can be put into use only when there is a ready supply of locally available topsoil. In absence of topsoil, dewatered biosolids, composted chicken manure or green waste and other organic amendments can be used. In addition, organic mulches can be spread over the surface, to mimic a temporary soil cover. This combination is exceptionally useful during preliminary stages of establishing vegetation on fly ash lagoons (Jusaitis and Pillman, 1997). Mulches have following major roles in reclamation processes: (i) curtailing water loss through evaporation and lessening surface temperature, (ii) diminishing erosion by wind and rain thus adding to soil stability, (iii) improving infiltration and water holding capacity of the soil, (iv) accretion of soil organic matter, (iv) and reducing weed germination (Haynes, 2009). Chemical amendments, such as EDTA, limestone although enhance phytoremediation process but are generally toxic (Evangelou et al., 2007) to both plants and beneficial soil microorganisms. Organic amendments provide a source for slowrelease of nutrients, improve soil physico-chemical biological conditions, increase water retention capacity and help to establish a self-sustaining microbial community in the substrate (Haynes 2009). One of the mostly used and upcoming amendments in recent times is biochar, a charcoal like residue leftover after pyrolysis of biomass. It is 
relatively stable and inert in nature and its inclusion into substrate is a pathway for $\mathrm{C}$ sequestration. Addition of biochar greatly increases water retention capacity and helps developing the soil microbial community of the soil (Belyaeva and Haynes 2012).

A great number of studies have been carried out by blending sandy topsoil/farmyard manure/mill mud/compost/biosolids/sewage sludge with ash dams, fly ash landfills to ascertain the positive effect of organic amendments on revegetation of degraded lands (Juwarkar and Jambhulkar, 2008; Schwab et al., 1989). Cheung et al., 2000 used 30\% vermiculite as well as sewage sludge compost (w/w) in pot scale studies with lagoon ash. However field studies provide more valuable information about potential revegetation of ash. Studies have shown that field practices of revegetation on FA deposits require utilization of high rate of fertilization and addition of NPK in absence of topsoil. This is essential for initial establishment of green cover. According to agronomic techniques mineral fertilizer containing NPK is used in the ratio 15:15:15 or 19:19:19 for initial fertilization to a root tilled depth of $8 \mathrm{~cm}$, which can be made by using $228 \mathrm{~kg}$ Urea, $90 \mathrm{~kg} \mathrm{P}_{2} 0$ and $90 \mathrm{~kg} \mathrm{~K}_{2} \mathrm{O}$ per ha. Amendments are usually applied in $5 \mathrm{~cm}$ layers and then root tilled to depth of $15 \mathrm{~cm}$ (Punshon et al., 2002).

\section{Microbial amendments}

FA being toxic in nature to living organisms is desolated of microbial activity and microbes, usually comprised of heterotrophic microflora, $\mathrm{N}_{2}$-fixing bacteria and mycorrhizal fungi. Despite of the fact, that these microbes are gradually brought into the site from neighboring soils, predominantly in the form of air-borne inoculums, FA makes it a tough medium for their survival and colonization (Sinha and Gupta, 2005). Notwithstanding all this, different species of mycorrhiza as well as Rhizobium have been found to possess varying range of survival potentials on FA medium (Juwarkar and Jambhulkar, 2008). The tolerant fungi and bacteria get the advantage of being selected during progressive vegetation establishment, forming symbiotic associations with existing and invading plant species leading to beneficial outputs. Mycorrhiza plant consortium increase the effective root volume of plants by more than eighty times and help them to scavenge nutrients and water. In augmentation with this mycorrhiza also protect plants against heavy metal-induced oxidative stress. Leguminous plants fix atmospheric nitrogen in association with Rhizobium bacteria to increase soil $\mathrm{N}$ (Juwarkar and Jambhulkar, 2008). Furthermore, there exists specificity in symbiotic association of legumes and strains of Rhizobium and accordingly leguminous seeds or plants are often inoculated with appropriate Rhizobium strain. In some studies, rhizobial and mycorrhizal inoculums had been isolated from an already revegetated site in view of their tolerance to the FA medium (Juwarkar and Jambhulkar, 2008). Some non leguminous trees have also been found to be symbiotically associated with $\mathrm{N}_{2}$-fixing organisms (e.g. Alnus spp), and can also aid in forming vegetation cover on ash deposits. Sometimes, locally available organic wastes (eg. press-mud, sewage sludge, municipal solid waste etc.) can also be blended or inoculated with FA-tolerant bacteria (Pandey et al., 2009b). Long term carbon sequestration in soil can be mediated through the priming effect of fungi (Fontaine et al., 2011). In a study carried out in south-eastern USA it has been reported that fungal endophyte infection increases carbon sequestration potential of tall fescue stands (Iqbal et al., 2012).

Amendments also help in reduced leaching of harmful trace metals from the substrate for example Zhou et al. (2014) showed decreased heavy metal concentrations in plants compared to control soil which contained no amendments. Percentage of 
inhibition increases with increasing doses of amendments. They help plants sequester heavy metals and assist in phytoremediation. Recently, microbe mediated processes of metal uptake by plants are being studied (Ma et al., 2011). Microbial metabolites in the rhizosphere alter metal mobility and bioavailabity in turn being biodegradable, less toxic and can be easily produced in situ in rhizospheric soils. Plant-associated microbes also produce some growth promoting substances such as siderophores, growth hormones; 1-amino cyclopropane-1-carboxylic acid (ACC) deaminase which further improve vegetation growth (Babu and Reddy, 2011).

\section{Trace metal availability and uptake by plants from fly ash}

\section{Bioavailability of metals}

Heavy metals are one of the toxic pollutants present in FA which cannot be degraded and hence persist in the substrate. Bioavailable metals is the fraction of the total metal contaminant in the substrate which is actually available to the receptor organisms, such as plants, microbes or humans and the extent to which these chemicals may become involved in the metabolism of the organism. Dynamics of metals is most active in surface layers due to their interaction with diverse microbes, higher organic matter content and cation exchange capacity. Microorganisms sequester/bioaccumulate trace metals from even very low concentrations in the substrate. The accumulation is the result of either (i) biosorption or (ii) physiological uptake through metabolic processes. Trace metals, once deposited in soil also interact with the soil minerals and organic constituents and this depends on soil properties $(\mathrm{pH}$, nature of organic as well as inorganic anions) and environmental factors. The charged metal ions get attached to the charged soil surface by electrostatic or other specific bonds (Ma et al., 2011). A pH value $>6$ lowers the concentration of free metal ions in the soils due to increased surface charge on oxides of $\mathrm{Fe}, \mathrm{Al}$ and $\mathrm{Mn}$ and chelation by organic matter. Higher $\mathrm{pH}$ also causes precipitation of metals and causes metal immobilization in the presence of anions such as sulfate, carbonate, hydroxide and phosphate (Adriano, 2001). Formation of complexes by trace metals and the general order of their affinity to get complexed with organic matter are in the following sequence (Adriano et al., 2004): $\mathrm{Cu}^{2+}>\mathrm{Cd}^{2+}>\mathrm{Mn}^{2+}$ $>\mathrm{Fe}^{2+}>\mathrm{Zn}^{2+}>\mathrm{Pb}^{2+}>\mathrm{Ni}^{2+}>\mathrm{Co}^{2+}$. In the natural environment, deposited metals undergo natural attenuation or remediation through transformation of their labile or bioavailable fraction (i.e., ion pair, those weakly adsorbed on exchange surface or complexed with humic ligands) (National Research Council, 2003; Campbell, 1995).

The natural remediation and uptake by plant roots has been depicted in Figure 4. The whole process is divided into four phases. Metal partitioning between solid and liquid phase is guided by processes such as adsorption, precipitation, complexation and redox reactions. This completes phase A which encompasses the base for bioavailability of metals. Phase (B, B') involves the transport of metal to the organism in soluble or colloidal form. This phase can also become an exposure pathway to grazing livestock through ingestion of soil particles while feeding on contaminated pastures. Colloidal form of metal transportation involves organic matter and is highly reactive. It contains higher metal concentration in comparison to those in the solution. Phase $\mathrm{C}$ involves passing of the metals through a biological membrane or root membranes. Roots also serve as a biofilter for contaminants. Phase D or the last phase involves circulation and assimilation of metals in the metabolic machinery of the organism and resulting into a biological response which may include growth and biomass of the organisms (Adriano 
et al., 2004). Transfer of metals from soil to plant is a very complex process and is governed by natural as well as anthropogenic factors (Rodriguez et al., 2011). Baker and Walker (1990) suggested that uptake, translocation and bioaccumulation mechanisms differed for various heavy metals and for the plant species.

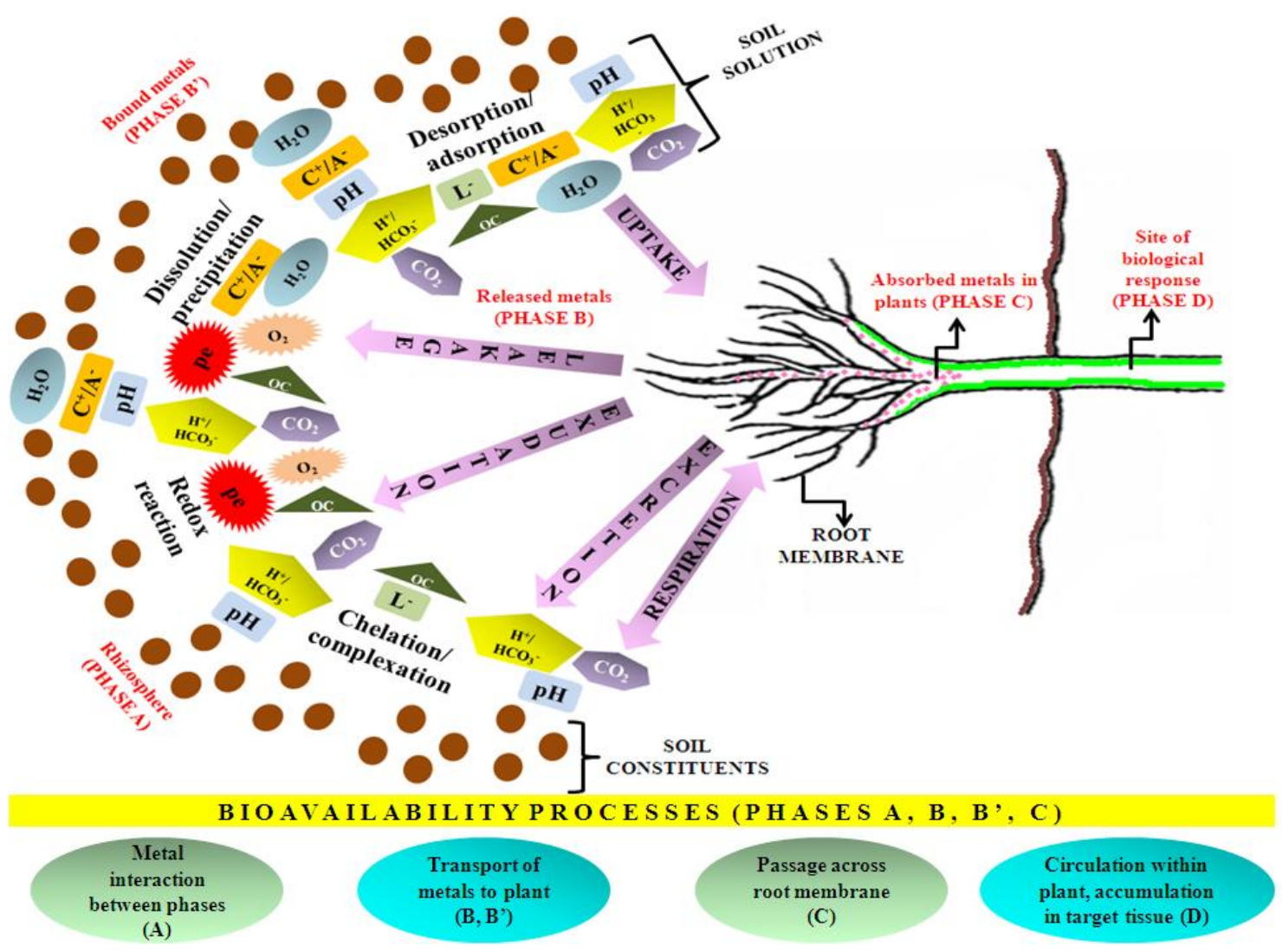

Figure 4. Bioavailability processes for metals in the rhizosphere of plants, emphasizing the mechanisms in soil solution interface. Legends: $O C=$ organic carbon; $C+=$ cation; $A+=$ anion; $L_{-}^{-}=$ligand; $p e=$ redox potential. Modified from Adriano et al., 2004.

\section{Trace metal extraction procedures}

Bioavailability tests are generally conducted to examine the effects of toxic metals leached from ash on living organisms (Shim et al., 2005). Generally various single extractions as well as sequential extraction procedures are used for estimation of and distribution of various chemical forms of a metal in soils/sediments. They include mineral acids (e.g., $1 \mathrm{~N} \mathrm{HCl}$ or $1 \mathrm{~N} \mathrm{HNO}_{3}$ ), salt solutions (e.g., $0.1 \mathrm{M} \mathrm{CaCl}_{2}$ ), buffer solutions (e.g.,

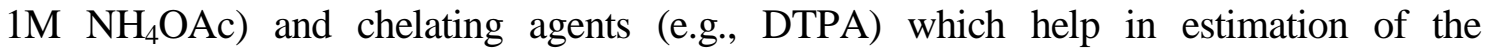
bioavailable fraction of trace elements in soils (van der Watt et al., 1994). In a study, Zhou et al. (2014) prepared the extracts by suspending soil in $1 \mathrm{M} \mathrm{MgCl}_{2}$ solution in 1:10 ratio $\mathrm{w} / \mathrm{v}$ and shaking at $150 \mathrm{rpm}$ at room temperature for $2 \mathrm{~h}$ followed by separating the extracts by centrifuging at $4000 \mathrm{rpm}$ for $10 \mathrm{~min}$ and filtering out the solid. Phytoavailable metals in FA and soil are also determined by DTPA extraction protocol (Lindsay and Norvell, 1978). Mehlich I and III are also being used to extract soil micronutrients in 1:4 and 1:8 ratio of w/v respectively. Mehlich I is composed of $0.0125 \mathrm{M} \mathrm{H}_{2} \mathrm{SO}_{4}+0.025 \mathrm{M} \mathrm{HCl}$ while Mehlich 
III is made by mixing $0.2 \mathrm{~N} \mathrm{CH}_{3} \mathrm{COOH}+0.25 \mathrm{~N} \mathrm{NH}_{4} \mathrm{NO}_{3}+0.013 \mathrm{~N} \mathrm{HNO}_{3}+0.015 \mathrm{~N} \mathrm{NH} 4 \mathrm{~F}$ $+0.001 \mathrm{M}$ EDTA (Mylavarapu et al., 2002).

On the other hand, leaching tests are a group of protocols which are carried out to find the rate of leaching and release of metals as a function of $\mathrm{pH}$ (Shim et al., 2005). Shim et al

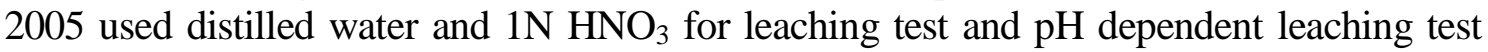
respectively. The toxicity characteristic leaching procedure (TCLP) is also the method of choice accepted by the USEPA for determining the amounts of potential toxic materials that could potentially leach from the soil and fly ash samples by $0.57 \%$ glacial acetic (USEPA, 1992). TCLP was also followed in various studies (Xenidis et al., 2003; Zhou et al., 2014) to monitor the release of trace metals from contaminated soil by extracting $5 \mathrm{~g}$ of sample with $100 \mathrm{~mL}$ of extractant on a rotary extractor at $30 \mathrm{rpm}$ for $18 \mathrm{~h}$. The extracts are filtered and processed for further analysis. Table 5 depicts the range of metals released by various reagents with values below and above the general regulatory limits given by different countries which are also called soluble threshold limit concentration.

Table 5. Available concentration of metals ( $\mathrm{mg} \mathrm{kg}-1)$ in fly ash, obtained by extracting with various reagents by different workers. The concentrations are compared to soluble threshold limit concentration.

\begin{tabular}{|c|c|c|c|c|c|c|}
\hline \multirow{2}{*}{$\begin{array}{l}\text { Metals } \\
\left(\mathrm{mg} \mathrm{kg}^{-1}\right)\end{array}$} & \multicolumn{5}{|c|}{ Extractant used } & \multirow[t]{2}{*}{ STLC $^{\#}$} \\
\hline & $\begin{array}{l}\text { Deionized } \\
\text { water/ } \\
\text { distilled } \\
\text { water }^{\mathrm{a}}\end{array}$ & $\begin{array}{l}\text { 0.05M } \\
\text { DTPA- } \\
\mathrm{CaCl}_{2}^{\text {b,e }}\end{array}$ & $\begin{array}{l}\text { 1N } \\
\mathrm{HNO}_{3}{ }^{\mathrm{b}, \mathrm{e}}\end{array}$ & $\begin{array}{l}\text { Mehlic } \\
\text { h I' }\end{array}$ & 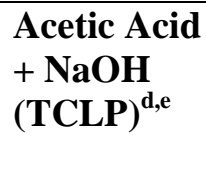 & \\
\hline $\begin{array}{l}\text { Sample: } \\
\text { solution (w/v) }\end{array}$ & $1: 10$ & $1: 2$ & $1: 10$ & $1: 4$ & $1: 20$ & $1: 20$ \\
\hline pH & $5.8-6.3$ & 7.3 & $3.5-4$ & 2.5 & 4.93 & 4.93 \\
\hline $\begin{array}{l}\text { Period of } \\
\text { extraction }\end{array}$ & $6 \mathrm{~h}$ & $2 \mathrm{~h}$ & $2 \mathrm{~h}$ & $4 \mathrm{~h}$ & $18 \mathrm{~h}$ & $18 \mathrm{~h}$ \\
\hline $\mathbf{F e}$ & $0.01-1.7$ & $8.2-21.9$ & 22.8 & 161 & $5.4-8.2$ & NA \\
\hline B & $0.1-1.1$ & 25 & 4 & 3 & 2.9 & NA \\
\hline Mn & $0.03-0.13$ & $0.41-3.5$ & 23.1 & 19 & 2.1 & NA \\
\hline Co & $0.02-0.06$ & $<0.05$ & 1.9 & 1.07 & 0.11 & 80 \\
\hline $\mathrm{Cu}$ & $0.01-0.02$ & $0.85-6.2$ & 4.5 & 11 & 0.48 & 25 \\
\hline$\overline{\mathbf{Z n}}$ & $0.02-4.8$ & 1.2 & 7.4 & 4.6 & 2.4 & 250 \\
\hline $\mathbf{N i}$ & 0.01 & $0.09-0.56$ & 1.4 & 2.3 & 0.25 & 20 \\
\hline Se & 0.1 & 1.1 & 0.84 & 0.35 & 0.12 & $0.3-1$ \\
\hline As & 0.1 & $0.6-4.7$ & 0.91 & 16 & 0.29 & $0.3-5$ \\
\hline Cd & $0.01-0.71$ & $0.14-0.34$ & 0.14 & 0.12 & 0.02 & $0.3-1$ \\
\hline $\mathrm{Cr}$ & $0.03-0.86$ & $0.94-2.1$ & 1.6 & 1.3 & 0.05 & 5 \\
\hline Hg & BDL & 0.04 & 0.07 & 0.07 & 0.08 & 0.2 \\
\hline $\mathbf{P b}$ & $0.07-1.10$ & $0.38-1.8$ & 2.2 & $<0.1$ & 0.004 & $0.3-5$ \\
\hline $\mathbf{B a}$ & 0.04 & $0.2-15$ & $0.2-15$ & 0.63 & 1.7 & 100 \\
\hline$\overline{\mathbf{A g}}$ & BDL & NA & NA & $<0.25$ & $\mathrm{BDL}$ & 5 \\
\hline
\end{tabular}

NA: not available; BDL: below detection limit; STLC: soluble threshold limit concentration.

${ }_{\text {a,e }}$ Shim et al., 2005

${ }^{\mathrm{b}}$ Lindsay and Norvell, 1978; Nayak et al., 2014

${ }^{\mathrm{c}}$ Punshon et al., 2002

${ }^{\mathrm{d} U S E P A, ~ 1992 ; ~ Z h o u ~ e t ~ a l ; ~} 2014$

${ }^{\mathrm{e}}$ Ward et al., 2003; Pandey et al., 2016

"Shim et al., 2005 
Usually, if the amount of trace metals released from the FA exceeds the regulatory limits it is grouped under hazardous waste (Shim et al., 2005). All the toxic elements are generally found within the STLC levels except Se and As. It has been reported that leachability of Se and As is variable in different leaching conditions (Ward et al., 2003). Leachability of As is significantly guided by the $\mathrm{pH}$ of the extractant which peaks at the middle of the $\mathrm{pH}$ range and lowers at the ends (Ward et al., 2003).

\section{Factors assessing phytoremediation potential of plants and pollution level in FA}

Decontamination/detoxification processes mediated through plants also called "phytoremediation" can render contaminated substrate harmless. This further improves soil biological activity, structure, and fertility (Salt et al., 1998). Fe, $\mathrm{Si}, \mathrm{As}, \mathrm{Cd}, \mathrm{Pb}$ is some examples of the various trace elements found in FA. Studies have reported that treated FA generally has lower quantities of toxic metals compared to untreated ones. It has also been observed that concentration of metals decreases during gradual weathering and revegetation processes (Kumari et al., 2013). Phytoremediation of heavy metals involves two basic processes:

1. Phytoextraction - metal accumulation by hyperaccumulator plants from soil in their harvestable parts, which after a certain time period are harvested, disposed or incinerated.

2. Phytostabilization is captivating metals and preventing their leaching with the help of adventious roots along with associated rhizospheric microbes. Phytostabilization has become the most successful and well approved process.

Differing metal contents within various plant parts are due to different cellular mechanisms which control their translocation in plant systems. Hyper-accumulation of a metal by a plant is judged by two dimensionless parameters (Gonzaga et al., 2006):

1. Bioaccumulation factor (BAF) is the ratio of metal concentration in roots to that in substrate. BAF values greater than 1 indicate the potentiality of the plant to be used for phytoremediation (Kumari et al., 2013). This factor can be calculated in the similar way for stems and leaves (Pandey, 2012a). Various plant species with different values of BAF have been enumerated in Table 4.

2. Bioabsorption coefficient (BAC) is metal content in shoot/metal content in soil (Varun et al., 2012).

3. Translocation factor (TF) is the concentration of metal accumulated in above ground part (shoot) by that accumulated in below ground part (root) of a plant. Various plant species with different values of TF have been enumerated in Table 4.

4. Metal pollution Index (MPI) finds out the relationships between metal load in roots and shoots and can be calculated by the following formulae (Singh et al., 2008), where $\mathrm{C}_{\mathrm{f}}$ is the concentration factor or metal concentration of $\mathrm{n}$ metals in a sample. In this context concentration factor of a metal can be determined by dividing a particular metal concentration in the sample by the concentration in the background.

$$
\mathrm{MPI}=\sqrt[n]{(\mathrm{Cf} 1 \times \mathrm{Cf} 2 \times \mathrm{Cf} 3 \times \ldots . \mathrm{Cfn})}
$$

5. Enrichment factor $\left(E_{f}\right)$ is determined by comparing accumulated trace metals with background concentration (Sinex and Helz, 1981) and can be calculated by 
the below formulae. $\mathrm{E}_{\mathrm{f}}$ and MPI do not involve threshold values of metals in samples during calculation, which is a drawback.

$$
\text { Enrichment factor }=\frac{\mathrm{TM}}{\text { Background }}
$$

6. Enrichment Index (EI) is calculated by averaging the ratios of element concentration to a threshold or permissible level. The permissible levels of metals in soil and FA are given in Table 3, which shows the maximum allowable limit of metals in the substrate to be safe for growth of food crops (Das and Chakrapani, 2011). For example the formulae for 5 metals will be as follows, where metal symbols represent metal concentration in the sample.

$$
\mathrm{EI}=\frac{1}{5}\left(\frac{\mathrm{Cr}}{25}+\frac{\mathrm{Cu}}{150}+\frac{\mathrm{Ni}}{60}+\frac{\mathrm{Zn}}{300}+\frac{\mathrm{Pb}}{300}\right)
$$

7. Geoaccumulation index $\left(I_{\text {geo }}\right)$ (Ruiz, 2001) is another index similar to enrichment index and calculated for quantification of metal in the substrate in relation to the background. It is expressed by the following formulae where $C_{n}$ is the metal concentration in the sample and $B_{n}$ is the background value whereas 1.5 is the background matrix correlation.

$$
\text { Igeo }=\log _{2} \frac{\mathrm{Cn}}{1.5 \times \mathrm{Bn}}
$$

$I_{\text {geo }}$ can be classified into six grades according to the values obtained, such as:

- Grade 1: unpolluted when $\mathrm{I}_{\text {geo }}<1$

- Grade 2: very lightly polluted when $1<\mathrm{I}_{\text {geo }}<2$

- Grade 3: lightly polluted when $2<\mathrm{I}_{\text {geo }}<3$

- Grade 4: moderately polluted when $3<\mathrm{I}_{\text {geo }}<4$

- Grade 5: highly polluted when $4<\mathrm{I}_{\text {geo }}<5$

- Grade 6: very highly polluted when $5<\mathrm{I}_{\text {geo }}<6$

Background values in the above formula can be substituted by the maximum allowable concentration or the threshold limit.

The above indexes can be used to determine the metal pollution level in plants as well as the substrate. They are very helpful in performing comparisons between differently reclaimed FA dumps. Moreover, intial studies for species selection for a future restoration programme can also be done on the basis of these indexes. Growing of hyperaccumulator species in restoration programmes is another aspect in which heavy metals contamination can be remediated from FA sites (Mendez and Maier, 2008). Pandey (2012a) reported that naturally growing Azolla caroliniana (water fern) on metal enriched FA ponds can be beneficial due to its toxitolerant characteristics such as high bioconcentration factor (BCF). A. caroliniana had high BCF values for all metals in roots and fronds in the range from 1.7 to 18.6 and 1.8 to 11.0 , respectively while TF ranged from 0.37 to 1.4 for various heavy metals (Pandey, 2012a). Biomass of this fern doubles in 3-9 days, depending on habitat conditions and success of 
phytoremediation depends on growth rate of the plant. Physicochemical and biological factors such as $\mathrm{pH}$, soil mineralogy, texture, salinity, amount of humic acids, and presence of organic chelators are responsible for metal availability and bioaccumulation in the plants (Pandey et al., 2010). Pandey (2013) studied about the potentiality of Ricinus communis L. to be used as a vegetation cover on metal enriched FA site and found that it has a BCF value greater than 1 and TF less than 1. T. dentata, is another a fern species which accumulates more metals in their roots/rhizome than the fronds (Kumari et al., 2011). Pandey et al. (2010) also found higher metal concentrations in root parts of chickpea growing on FA. The tendency of plants to accumulate metals in their aboveground and below ground parts is directly proportional to amount and time of exposure to the fly ash. Metals are generally sequestered in the root cell vacuoles to diminish its toxicity. Roots often act as a barrier against heavy metal translocation and are more tolerant to toxic metal concentrations, thus explaining higher accumulation when compared to shoots (Shanker et al., 2005).

\section{Conclusion}

In conclusion, this paper emphasizes on an efficient reclamation strategy of FA disposal sites which are a foremost challenge nowadays to check land and environment degradation. Above discussion on FA characteristics, enrichment and geo-accumulation index of toxic metals can be considered before initiating technical restoration on the site. A prior survey on the FA properties such as $\mathrm{pH}$, texture, metal leaching should be carried out before selecting the type of amendment application, rate of application and type of plant species to be used. This would also help in reducing ground water contamination. Use of geotextiles is also recommended in certain cases to curtail erosion of FA during monsoon.

Plant species such as fast growing legumes act as green manure whereas hardy tuft grasses act as mulches. They can reduce the use of costly topsoil and also require less manure. Knowledge of the phytodiversity of old FA deposits and also the inventory discussed in this paper will help in selecting a right combination of native and exotic species for gradual restoration of the sites. In addition, rapidly growing perennial cover species, mixed plantation of grasses and legumes ameliorates the substrate, stabilises toxic metals, produces sufficient aboveground biomass, prevents erosion and can also lend a future source of income for local people. Biomass production is a new prospect in FA landfills management and can be initiated at later stages of restoration. Economically important trees which generate pulp, paper, biodiesel, firewood, timber wood, plywood, aromatic grasses yielding essential oils, fast growing legumes producing non timber forest products should be practised efficiently in these areas.

Above all this, a regular monitoring schedule is of prime importance in each restoration programme. Time to time analysis of substrate nutrient status, extent of nutrient loss, bioavailable toxic metals, and their accumulation in the vegetation will help in guiding the future steps to improve the status of these sites. This type of monitoring data emphasizing on the long term change in FA properties due to vegetation and metal leaching into ground water will benefit the future approaches to be used in management of FA deposits. 


\section{REFERENCES}

[1] Adriano, D.C., Wenzel, W.W., Vangronsveld, J., Bolan, N.S. (2004): Role of assisted natural remediation in environmental cleanup. - Geoderma 122: 121-142.

[2] Adriano, D.C., Page, A.L., Elseewi, A.A., Chang, A., Straughan, I.A. (1980): Utilization and disposal of fly ash and other coal residues in terrestrial ecosystem: a review. - Journal of Environment Quality 9: 333-344.

[3] Adriano, D.C., Weber, J.T. (2001): Influence of fly-ash on soil physical properties and turfgrass establishment. - Journal of Environmental Quality 30: 596-601.

[4] Akhila, A. (2010): Essential Oil-bearing Grasses: The genus Cymbopogon. Medical and aromatic plants-industrial profile. - Taylor and Francis Group, L.L.C

[5] Alloway, B.J. (2013): Heavy Metals in Soils: Trace Metals and Metalloids in Soils and their Bioavailability. - Springer, Netherlands

[6] Alonso, J.L., Wesche, K. (1991): Characterization of fly ash. - In: Wesche, K. (ed.) Fly Ash in Concrete Properties and Performance, E \& FN SPON e, An Imprint of Chapman \& Hall

[7] Asokan, P., Saxena, M., Asolekar, S. R. (2005): Coal combustion residues environmental implications and recycling potentials. - Resources Conservation Recyling 43: 239-262.

[8] Babu, A.G., Reddy, S. (2011): Dual inoculation of arbuscular mycorrhizal and phosphate solubilizing fungi contributes in sustainable maintenance of plant health in fly ash ponds. -Water Air Soil Pollution 219: 3-10.

[9] Baker, A.J.M., Walker, P.L. (1990): Ecophysiology of metal uptake by tolerant plants. In: Shaw, A.J. (ed.) Heavy Metal Tolerance in Plants: Evolutionary Aspects, CRC Press, Boca Raton, FL

[10] Belyaeva, N.O., Haynes, J.R. (2012): Comparison of the effects of conventional organic amendments and biochar on the chemical, physical and microbial properties of coal fly ash as a plant growth medium. - Environmental Earth Sciences 66:1987-1997.

[11] Branzini, A., Gonzalez, R.S., Zubillaga, M. (2012): Absorption and translocation of copper, zinc and chromium by Sesbania virgata. - Journal of Environment Management 102: 50-54.

[12] Brindle, F.A. (2003): Use of native vegetation and biostimulants for controlling soil erosion on steep terrain. - Journal of the Transportation Research Board 1: 203- 209.

[13] Bryan, A.L., Hopkins, W.A., Parikh, J.H., Jackson, B.P., Unrine, J.M. (2012): Coal fly ash basins as an attractive nuisance to birds: parental provisioning exposes nestlingsto harmful trace elements. - Environmental Pollution 161: 170-177.

[14] Campbell, P.G.C. (1995): Metal Speciation and Bioavailability in Aquatic Systems. - In: Tessier, A., Turner, D.R. (ed.) Wiley, New York

[15] Carlson, C.L., Adriano, D.C. (1991): Growth and elemental content of two tree species growing on abandoned coal fly ash basins. - Journal of Environment Quality 20: 581-587.

[16] CEA (Central Electricity Authority). (2012): Annual Report on Fly-ash utilization, Report on Fly Ash Generation at Coal/Lignite Based Thermal Power Stations and its Utilization in the Country for the Year 2011-12, New Delhi.

[17] Chaudhary, R.D., Ghosh, A. (2013): Bioaccumulation of nutrient elements from fly ashamended soil in Jatropha curcas L.: a biofuel crop. - Environmental Monitoring and Assessment 185: 6705-6712.

[18] Cheung, K.C., Wong, J.P.K., Zhang, Z.Q., Wong, J.W.C., Wong, M.H. (2000): Revegetation of lagoon ash using the legumes species Acacia auriculiformis and Leucaena leucocephala. -Environmental Pollution 109: 75-82.

[19] Das, S.K., Chakrapani G.J. (2011): Assessment of trace metal toxicity in soils of Raniganj Coalfield, India. - Environmental Monitoring and Assessment 177: 63-71. 
[20] El-Mogazi, D., Lisk, D.J., Weinstein, L.H. (1988): A review of physical, chemical, and biological properties of fly ash and effects on agricultural ecosystems. - Science of the Total Environment: 74: 1-37.

[21] Erich, M.S. (1991): Agronomic effectiveness of wood ash as a source of phosphorus and potassium. - Journal of Environment Quality 20: 576-581.

[22] Evangelou, M.W.H., Bauer, U., Ebel, M., Schaeffer, A. (2007): The influence of EDDS and EDTA on th uptake of heavy metals of $\mathrm{Cd}$ and $\mathrm{Cu}$ from soil with tobacco Nicotiana tabacum. - Chemosphere 68: 345-53.

[23] Fontaine, S., Henault, C., Aamor, A., Bdioui, N., Bloor, J.M.G., Maire, V., Mary, B., Revail-lot, S., Maron, P.A. (2011): Fungi mediate long term sequestration of carbon and nitrogen in soil through their priming effect. - Soil Biology and Biochemisty 43: 86-96.

[24] Gonzaga, M.I.S., Santos, J.A.G., Ma, L.Q. (2006): Arsenic phytoextraction and hyperaccumulation by fern species. - Scientia Agricola (Piracicaba, Braz) 63: 90-101.

[25] Gray, D.H., Sotir, R.B. (1996): Biotechnical and Soil Bioengineering Slope Stabilization: A Practical Guide for Erosion Control. - John Wiley and Sons, Toronto

[26] Grill, E., Winnacker, E. L., Zenk, M. H. (1991): Phytochelations. - In: Riordan, J. F., Valle, B. L. (ed.) Methods in Enzymology

[27] Gupta, A.K., Verma, S.K., Khan, K., Verma, R.K. (2013): Phytoremediation using aromatic plants: a sustainable approach for remediation of heavy metals polluted sites. Environmental Science and Technology 47: 10115-10116.

[28] Haynes, R. J. (2009): Reclamation and revegetation of fly ash disposal sites - challenges and research needs. - Journal of Environmental Management 90: 43-53.

[29] Høgh-Jensen, H., Schjoerring, J.K. (2000): Below-ground nitrogen transfer between different grasslands species: direct quantification by $15 \mathrm{~N}$ leaf feeding compared with indirect dilution of soil 15N. - Plant and Soil 227: 171-183.

[30] Iqbal, J., Siegrist, J.A., Nelson, J.A., McCulley, R.L. (2012): Fungal endophyte infectionincreases carbon sequestration potential of southeastern USA tall fescue stands. Soil Biology and Biochemisty 44: 81-92.

[31] Jain, K. A., Gaggar, S. (2013): Present status of availability, utilization and other options to increase effective use of fly ash in India. - Paper presented $3^{\text {rd }}$ Annual International Summit: FLY ASH UTILISATION, New Delhi, India, Mission Energy Foundation, Mumbai, India

[32] Jambhulkar, H. P., Juwarkar, A. A. (2009): Assessment of bioaccumulation of heavy metals by different plant species grown on fly ash dump. - Ecotoxicology and Environmental Safety 72: 1122-1128.

[33] Jayasinghe, G.Y., Tokashiki, Y. (2012): Influence of coal fly ash pellet aggregates on the growth and nutrient composition of Brassica campestris and physicochemical properties of greysoils in Okinawa. - Jornal of Plant Nutrition 35: 47-453.

[34] Jusaitis, M., Pillman, A. (1997): Revegetation of waste fly ash lagoons. I. Plant selection and surface amelioration. - Waste Management and Research 15: 307-321.

[35] Juwarkar, A. A., Jambhulkar, H. P. (2008): Restoration of fly ash dump through biological interventions. - Environmental Monitoring and Assessment 139: 355-365.

[36] Kabata-Pendias A., Sadurski W. (2004): Elements and their compounds in the environment. - Wiley-VCH, Weinheim

[37] Khajanchi, L., Yadava, R.K., Kaurb, R., Bundelaa, D.S., Khana, M.I., Chaudharya, M., Meenaa, R.L., Dara, S.R., Singha, G. (2013): Productivity essential oil yield, and heavy metal accumulation in lemon grass (Cymbopogon flexuosus) under varied wastewatergroundwater irrigation regimes. - Industrial Crops and Products 45: 270-278.

[38] Kim, B.J., Back, J.H., Kim, Y.S. (1997): Effect of fly ash on the yield of Chinese cabbage and chemical properties of soil. Korean Journal of Soil Science and Fertilizer 30: 161167. 
[39] Kumar, K.V., Patra, D. D. (2012): Alteration in yield and chemical composition of essential oil of Mentha piperita L. plant: effect of fly ash amendments and organic wastes. - Ecological Engineering 47: 237-241.

[40] Kumari, A., Pandey, C. V., Rai, N. U. (2013): Feasibility of fern Thelypteris dentata for revegetation of coal fly ash landfills. - Journal of Geochemical Exploration 128: 147-152.

[41] Kumari, A., Lal, B., Pakade, Y.B., Chand, P. (2011): Assessment of bioaccumulation of heavy metal by Pteris vittata L. growing in the vicinity of fly ash. - International Journal of Phytoremediation 13: 779-787.

[42] Lau, S.S.S., Wong, J.W.C. (2001): Toxicity evaluation of weathered coal fly ash amended manure compost. - Water Air and Soil Pollution 128: 243-254.

[43] Lazzarotto, P., Calanca, P., Fuhrer, J. (2009): Dynamics of grass-clover mixtures: an analysis of the response to management with the productive grassland simulator. (Prograss). - Ecological Modelling 220: 703-724.

[44] Lee, H., Ho, S.H., Lee, C.H., Lee, Y.B., Kim, P.J. (2006): Fly ash effect on improving soil properties and rice productivity in Korean paddy soils. - Bioresource Technology 97: 1490-1497.

[45] Lenka, K.N., Choudhury, R.P., Sudhishri, S., Dass, A., Patnaik, S.U. (2012): Soil aggregation, carbon build up and root zone soil moisture in degraded sloping lands under selected agroforestry based rehabilitation systems in eastern India. - Agriculture ecosystems and environment 150: 54-62.

[46] Linares, S., Gonzalez, N., Gómez, E., Usubillaga, A., Darghan, E. (2005): Effect of the fertilization, plant density and time of cutting on yield and quality of the essential oil of Cymbopogon citratus Stapf. - Revista de la Facultad de Agronomía LUZ 22: 247-260.

[47] Lindsay, W. L., Norvell, W. A. (1978): Development of DTPA soil test for Zn, Fe, Mn and $\mathrm{Cu}$. - Soil Science Society of America Journal 42: 421-428.

[48] Liu, G.D., Phaikaew, C., Stur, W.W. (1997): Status of Stylosanthes development in other countries. II. Stylosanthes development and utilization in China and south-east Asia. Tropic Grasslands 31: 460-466.

[49] Ma, Y., Prasad, M.N.V., Rajkumar, M., Freitas, H. (2011): Plant growth promoting rhizobacteria and endophytes accelerate phytoremediation of metalliferous soils. Biotechnology Advances 29: 248-58.

[50] Madejon, E., De Mora, A. P., Felipe, E., Burgos, P., Cabrera, F. (2006): Soil amendments reduce trace element solubility in a contaminated soil and allow regrowth of natural vegetation. - Environment Pollution 139: 40 - 52.

[51] Maiti, S. K., Maiti, D. (2015): Ecological restoration of waste dumps by topsoil blanketing, coir-matting and seeding with grass-legume mixture. - Ecological Engineering 77: 74-84.

[52] Mathur, R., Chand, S., Tezuka, T. (2003): Optimal use of coal for the power generation in India. - Energy Policy 31: 319-331.

[53] Mattigod, S.V., Rai, D., Eary, L.F., Ainsworth, C.C. (1990): Geochemical factors controlling the mobilization of inorganic constituents fromfossil fuel combustion residues: I. Review of the major elements. - Journal of Environmental Quality 19: 188-201.

[54] Mendez, M.O., Maier, R.M. (2008): Phytostabilization of mine tailings in arid and semiarid environments - an emerging remediation technology. - Environmental Heal Perspectives 116: 278-283.

[55] Milcu, A., Partsch, S., Scherber, C., Weisser, W.W., Scheu, S. (2008): Earthworms and legumes control litter decomposition in a plant diversity gradient. - Ecology 89: 18721882.

[56] Mitrovic, M., Pavlovic, P., Lakusic, D., Djurdjevic, L., Stevanovic, B., Kostic, O., Gajic, G. (2008): The potential of Festuca rubra and Calamagrostis epigejos for the revegetation of fly ash deposits. - Science of the total environment 407: 338-347.

[57] Morgan, R.P.C. (2005): Soil Erosion and Conservation. - Blackwell Publishing, Oxford, UK. 
[58] Mylavarapu, R.S., Sanchez, J.F., Nguyen J.H. Bartos J. M. (2002): Evaluation of Mehlich-1 and Mehlich-3 extraction procedures for plant nutrients in acid mineral soils of Florida. - Communications in Soil Science and Plant Analysis 33: 807-820.

[59] National Research Council (NRC). (2003): Bioavailability of contaminants in soils and sediments: processes, tools and applications. Com. on Bioavailability of Contaminants in Soils and Sediments. - Natl. Academy Press, Washington, DC

[60] Nayak, K.A., Raja, R., Rao, K.S., Shukla, K.A., Mohanty, S., Shahid, M., Tripathi, R., Panda, B.B., Bhattacharyya, P., Kumar, A., Lal, B., Sethi, K.S., Puri, C., Nayak, D., Swai, K. C. (2014): Effect of fly ash application on soil microbial response and heavy metal accumulation in soil and rice plant. - Ecotoxicology and Environmental Safety 114: 257262.

[61] Normaniza, O., Barakbah, S.S. (2011): The effect of plant succession on slope stability. Ecological Engineering 37: 139-147.

[62] Nyambura, M.G., Mugera, W.G., Felicia, P.L., Gathura, N.P. (2011): Carbonation of brine impacted fractionated coal fly ash: implications for $\mathrm{CO}_{2}$ sequestration. - Journal of Environmental Management 92: 655-664.

[63] O-Hara, G.W., Nantakorn, B., Dilworth, M. J. (1988): Mineral constraints to nitrogen fixation. - Plant and Soil 108: 93 - 110.

[64] Page, A.L., Elseewi, A.A., Straughan, I.R. (1979): Physical and chemical properties of fly-ash from coal-fired power plants with reference to environmental impacts. - Residue Review 71: 83-120.

[65] Paliwal, K.S. (2013): Environmental Issues and Regulations with respect to Flyash Management. Paper presented $3^{\text {rd }}$ Annual International Summit: FLY ASH UTILISATION, New Delhi, India. - Mission Energy Foundation, Mumbai, India

[66] Pandey, S.K., Bhattacharya, T., Chakraborty, Sukalyan. (2016): Metal phytoremediation potential of naturally growing plants on fly ash dumpsite of Patratu thermal power station, Jharkhand, India. - International journal of phytoremediation 18: 87-93.

[67] Pandey, V.C. (2013): Suitability of Ricinus communis L. cultivation for phytoremediation of fly ash disposal sites. - Ecological Engineering 57: 336-341.

[68] Pandey, V.C., Singh, K. (2011): Is Vigna radiata suitable for the revegetation of fly ash landfills? - Ecological Engineering 37: 2105-2106.

[69] Pandey, V.C. (2012a): Phytoremediation of heavy metals from fly ash pond by Azolla caroliniana. - Ecotoxicology and environmental safety 82: 8-12.

[70] Pandey, V.C. (2012b): Invasive species based efficient green technology for phytoremediation of fly ash deposits. - Journal of Geochemical Exploration 123: 3-18.

[71] Pandey, V.C., Abhilash, P.C., Singh, N. (2009): The Indian perspective of utilizing fly ash In phytoremediation, phytomanagement and biomass production. - Journal of Environmental Management 90: 2943-2958.

[72] Pandey, V. C., Bajpai, O., Pandey, D. N., Singh, N. (2015): Saccharum spontaneum: an underutilized tall grass for revegetation and restoration programs. - Genetic Resources and Crop Evolution 62: 443-450.

[73] Pandey, V.C., Prakash, P., Bajpai, O., Kumar, A., Singh, N. (2014b): Phytodiversity on fly ash deposits: evaluation of naturally colonized species for sustainable phytorestoration. -Environmental Science and Pollution Research 22(4): 2776-2787.

[74] Pandey, V.C., Singh, J.S., Kumar, A., Tewari, D.D. (2010): Accumulation of heavy metals by chickpea grown in FA treated soil: effect on antioxidants. - Clean - Soil Air Water 38: 1116-1123.

[75] Pandey, V.C., Singh, K., Singh, R.P., Singh, B. (2012): Naturally growing Saccharum munja on the fly ash lagoons: a potential ecological engineer for the revegetation and stabilization. -Ecological Engineering 40: 95-99.

[76] Pathak, P.S., Ramesh, C.R. and Bhatt, R.K. (2004): Stylosanthes in the reclamation and development of degraded soils in India. - In: High Yielding Anthracnose-Resistant Stylosanthes for Agricultural Systems, ACIAR, Australia 
[77] Patra, K.C., Rautray, T.R., Nayak, P. (2012a): Elemental analysis of coal and coal ash by PIXE technique. - Applied Radiation and Isotopes 70: 612-616.

[78] Prasad, B., Mortimer, R.J.G. (2011): Treatment of acid mine drainage using fly ash zeolite. - Water, Air, \& Soil Pollution 218: 667-679.

[79] Punshon, T., Adriano, D.C., Weber, J.T. (2002): Restoration of drastically eroded land using coal fly ash and poultry biosolid. - The Science of the Total Environment 296: 209225.

[80] Rajkumar, M., Ae, N., Prasad, M.N.V, Freitas, H. (2010): Potential of siderophoreproducing bacteria for improving heavy metal phytoextraction. - Trends in Biotechnology 28: $142-9$.

[81] Rai, U.N., Pandey, K., Sinha, S., Singh, A., Saxena, R., Gupta, D. K. (2004): Revegetating fly ash landfills with Prosopis juliflora L.: impact of different amendments and Rhizobium inoculation. - Environmental International 30: 293-300.

[82] Ram, L.C., Jha, S.K., Tripathi, R.C., Masto, R.E., Selvi, V.A. (2008): Remediation of fly ash landfills through plantation. - Remediation 18:71-90.

[83] Ram, L.C., Masto, R.E. (2010): An appraisal of the potential use of fly ash for reclaiming coal mine spoil. - Journal of Environmental Management 91: 603-617.

[84] Ram, L.C., Masto, R.E. (2014): Fly ash for soil amelioration: A review on the influence of ash blending with inorganic and organic amendments. - Earth Science Reviews 128: 52-74.

[85] Ramesh, C.R., Mal, B., Hazra, C.R., Sukanya, D.H., Ramamurthy, V., Chakraborty, S. (1997). Status of Stylosanthes development in other countries. III. Stylosanthes development and utilization in India. - Tropic Grasslands 31: 467-475.

[86] Rodriguez, J.H., Klumpp, A., Fangmerier, A., Pignata, M.L. (2011): Effects of elevated $\mathrm{CO} 2$ concentrations and fly ash amended soils on trace element accumulation and Translocation among roots, stems and seeds of Glycine max (L) Merr. - Journal of Hazardous Materials 187: 58-66.

[87] Ruiz, F. (2001): Trace metals in estuarine sediments from the southwestern Spanish coast. -Marine Pollution Bulletin 42: 482-490.

[88] Salt, D.E., Smith, R.D., Raskin, I. (1998): Phytoremediation. - Annual Review of Plant Physiology and Plant Molecular Biology 13: 468-74.

[89] Sarangi, P.K., Mahakur, D., Mishra, P.C. (2001): Soil biochemical activity and growth response of rice Oryza sativa in fly ash amended soil. - Bioresource Technology 76: 199205.

[90] Schwab, A.P., Ohlen busch, P.D., Tomecek, M.B. (1989): Revegetation of coal ash wastes without soil. An Interim Report - Agronomy Department, Throck morton Hall, Kansas State University, Kansas.

[91] Shanker, A.K., Carlos, C., Loza-Tavera, H., Avudainayagam, S. (2005): Chromium toxicity in plants. - Environment International 31: 739-753.

[92] Shim, Y.S., Rhee, S.W., Lee, W.K. (2005): Comparison of leaching characteristics of heavy metals from bottom and fly ashes in Korea and Japan. - Waste Management 25: 473-480.

[93] Sinex, S. A., Helz, G. R. (1981): Regional geochemistry of trace elements in Chesapeake Bay sediments. - Environmental Geology 3: 315-323.

[94] Singh, A.N., Raghubanshi, A.S., Singh, J.S. (2002): Plantations as a tool for mine spoil restoration. - Current Science 82: 1436-1441.

[95] Singh, S.J., Pandey, C.V. (2013): Fly ash application in nutrient poor agriculture soils: Impact on methanotrophs population dynamics and paddy yields. - Ecotoxicology and Environmental Safety 89: 43-51.

[96] Singh, A., Sharma, R.K., Agrawal, S.B. (2008): Effects of fly ash incorporation on heavy metal accumulation, growth and yield responses of Beta vulgaris plants. - Bioresource Technology 99: 7200-7207. 
[97] Sinha, S., Gupta, A.K. (2005): Translocation of metals from fly ash amended soil in the plant of Sesbania cannabina L. Ritz: Effect on antioxidants. - Chemosphere 61: 12041214.

[98] Sinha, S., Rai, U.N., Bhatt, K., Pandey, K., Gupta, A.K. (2005): Fly ash induced oxidative stress and tolerance in Prosopis juliflora L. grown on different amendments substrates. Environmental Monitoring and Assessment 102: 447-457.

[99] Spehn, E.M., Scherer-Lorenzen, M., Schmid, B., Hector, A., Caldeira, M.C., Dimitrakopoulos, P.G. (2002): The role of legumes as a component of biodiversity in a cross-European study of grassland biomass nitrogen. - Oikos 98: 205-218.

[100] Srivastava, M., Ma, L.Q., Singh, N., Singh, S. (2005): Antioxidant responses of hyperaccumulators and sensitive species to arsenic. - Journal of Experimental Botany 56: $1335-1342$.

[101] Stutzxna, P. E., Centeno, L. (1995): Compositional Analysis of Beneficiated Fly Ashes. NISTIR 5598. - National Institute of Standards and Technology, Gaithersburg

[102] Sugumaran, M., Joseph, S., Lee, K.L.W., Wong, K.W. (2005): Herbs of Malaysia. Shah Alam, Federal Publication.

[103] Taylor, Jr., E.M., Schuman, G.E. (1988): Fly ash and lime amendment of acidic coal spoil to aid revegetation. - Journal of Environmental Quality 17: 120-124.

[104] Tengbeh, G.T. (1993): The effect of grass roots on shear strength variations with moisture content. - Soil Technology 6: 287-295.

[105] Thomas, R.J., Asakawa, N.M., Rondon, M.A., Alarcon, H. F. (1997): Nitrogen fixation by three tropical forage legumes in an acid-soil savanna of Colombia. - Soil Biology and Biochemistry 29: 801-808.

[106] Tripathi, R.D., Dwivedi, S., Shukla, M.K., Mishra, S., Srivastava, S., Singh, R., Rai, U.N., Gupta, D.K. (2008): Role of blue green algae biofertilizer in ameliorating the nitrogen demand and fly-ash stress to the growth and yield of rice (Oryza sativa L.) plants. Chemosphere 70: 1919-1929.

[107] Tripathi, R.D., Vajpayee, P., Singh, N., Rai, U.N., Kumar, A., Ali, M.B., Kumar, B., Yunus, M. (2004): Efficacy of various amendments for amelioration of fly-ash toxicity: growth performance and metal composition of Cassia siamea Lamk. - Chemosphere 54: $1581-1588$.

[108] Ulery, A.L., Graham, R.C., Amrhein, C. (1993): Wood-ash composition and soil pH following intense burning. - Soil Science 156: 358-364.

[109] USEPA, (2007): Human and Ecological Risk Assessment of Coal Combustion Wastes. USEPA.

[110] USEPA. (1992): Method 1311: Toxicity characteristic leaching procedure. Test methods for evaluating solid waste physical/chemical methods. - Publ. SW-846, USEPA, Washington, DC.

[111] Van der Watt, H.V.H., Sumner, M.E., Cabrera, M.L. (1994): Bioavailability of copper, manganese and zinc in poultry manure. - Journal of Environmental Quality 23: 43- 49.

[112] Varun, M., D’Souza R., Pratas J., Paul, M.S. (2012): Metal contamination of soils and plants associated with the glass industry in North Central India: prospects of phytoremediation. - Environmental Science and Pollution Research 19: 269-281.

[113] Verma, S.K., Singh, K., Gupta, A.K., Pandey, V.C., Trivedi, P., Verma, R.K., Patra, D.D. (2014): Aromatic grasses for phytomanagement of coal fly ash hazards. - Ecological Engineering 73: 425-428.

[114] Wang, S. (2008): Application of solid ash based catalysts in heterogeneous catalysis. Environmental Science and Technology 42: 7055-7063.

[115] Wang, S., Wu, H. (2006): Environmental-benign utilization of fly ash as low-cost adsorbents. - Journal of Hazardous Materials 136: 482-501.

[116] Ward, C.R., French, D., Jankowski, J. (2003): Comparative evaluation of leachability test methods and element mobility for selected Australian fly ash samples. - Co-operative Research Centre for Coal in Sustainable Development, Technical Note: 1-22. 
[117] Wong, J.W.C., Wong, M.H. (1990): Effects of fly ash on yields and elemental composition of two vegetables, Brassica parachinensis and B. chinensis. - Agriculture Ecosystems and Environment 30: 251-264.

[118] Wong, M.H., Wong, J.W.C. (1989): Germination and seedling growth of vegetable crops in fly ash-amended soils. Agriculture Ecosystems and Environment 26: 23-35.

[119] Xenidis, A., Mylona, E., Paspaliaris, I. (2002): Potential use of lignite fly ash for the control of acid generation from sulphidic wastes. - Waste Management 22: 631-641.

[120] Zhou, H., Zhou, X., Zeng, M., Liao, B.H., Liu, L., Yang, W.T., Wu, Y.M., Qiu, Q.Y., Wang, Y.J. (2014): Effects of combined amendments on heavy metal accumulation in rice (Oryza sativa L.) planted on contaminated paddy soil. - Ecotoxicology and Environment Safety 101: 226-232.

[121] Zolnierz, L., Weber, J., Gilewska, M., Strączynska, S., Pruchniewicz, D. (2016): The spontaneous development of understory vegetation on reclaimed and afforested post-mine excavation filled with fly ash. - Catena 136: 84-90. 